\title{
HJalti Hugason
}

\section{Á hverfanda hveli \\ Um breytta stöðu pjóðkirkjunnar í ljósi sögunnar}

Staða íslensku kirkjunnar hefur breyst mikið frá pví sem var í sveitasamfélagi fyrri tíðar. Pessa verður mjög vart sé horft til peirra tveggja áratuga sem liðnir eru af tuttugustu og fyrstu öldinni. Mælanlegar breytingar á stöðu kirkjunnar hafa trúlega aldrei verið örari en einmitt á pessu skeiði. Pær koma ekki síst fram í hlutfallstölum peirra sem tilheyra pjóðkirkjunni, peirra sem játa trúarkenningum hennar og telja sig almennt eiga samleið með henni. Um aldamótin tilheyrðu um 89 prósent landsmanna pjóðkirkjunni. Tuttugu árum síðar var sú tala komin niður í 63,5 prósent og hafði pví lækkað um rúm 25 prósentustig. ${ }^{1}$ Hlýtur pað eitt að teljast róttæk breyting og réttlæta að staðhæft sé að staða pjóðkirkjunnar sé á hverfanda hveli. Próunina má vissulega skýra með ýmsu móti og parf raunar ekki að seilast aftur í aldir til pess eins og hér verður pó gert. Lýðfræðileg samsetning samfélagsins er til að mynda önnur nú en fyrir tuttugu árum. Um aldamótin töldust 2,6 prósent landsmanna hafa annan bakgrunn en íslenskan. Nú er hlutfallstalan 13,5 prósent. $^{2}$ Margir pessara nýju Íslendinga eiga rætur í annarri trúarhefo en peirri evangelísk-lúthersku og hafa pví ekki skráð sig í pjóðkirkjuna við flutning til landsins eða af öðrum ástæðum valið að standa utan hennar.

Petta skýrir próunina pó ekki til fulls. Pvert á móti er ljóst að staða pjóðkirkjunnar er einnig á hverfanda hveli meðal fólks með djúpar rætur

1 „Mannfjöldi eftir trú og lífsskoðunarfélögum 1998-2020“, Hagstofa Íslands, sótt 1. febrúar 2021 af https://px.hagstofa.is/pxis/pxweb/is/Samfelag/Samfelag_menning_5_trufelog/MAN10001.px/table/tableViewLayout1/? rxid=6bd0ee91-d9d7$43 \mathrm{~b} 4-\mathrm{a} 5 \mathrm{~d} 2-9 \mathrm{ea} 69 \mathrm{~d} 533 \mathrm{ca} 8$.

2 „Erlendir ríkisborgarar. Hlutfall af mannfjölda“, Hagstofa Íslands, sótt 1. febrúar 2021 af https:/hagstofa.is/talnaefni/ibuar/mannfjoldi/bakgrunnur/.

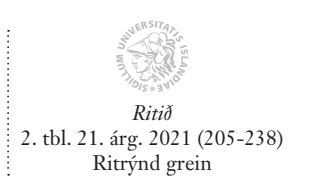

(C) 2021 Ritið, tímarit Hugvísindastofnunar og höfundar greinarinnar

Útgefandi:

Hugvísindastofnun Háskóla Íslands, Sæmundargötu 2, 102 Reykjavík
Birtist á vefnum http://www.ritid.hi.is. Tengiliður: ritið@hi.is

DOI: $10.33112 /$ ritid.21.2.10

Birt samkvæmt skilmálum Creative Commons BY (4.0). 
í íslensku samfélagi og menningu. Раð kemur meðal annars fram í að 2020 lýstu 61 prósent aðspurðra í könnun lífsskoðunarfélagsins Siðmenntar og könnunarfyrirtækisins Maskínu að pau játuðu kristna trú og hafði hlutfall peirra lækkað um rúm sjö prósent síðustu fimm árin. Pegar frekar var grafist fyrir um hvaða merkingu fólk lagði í að vera kristin/n kom í ljós að tæpt 31 prósent peirra sem lýsa afstöðu sinni svo virðast aðhyllast hefðbunda kirkjulega trú en afstaða annarra ráðast meira af siðferðilegum, félagslegum eða menningarlegum ástæðum sem ekki purfa að fela í sér persónulega trúarafstöðu. 2020 töldu tæp 42 prósent aðspurðra sig trúuð miðað við rúm 46 prósent fimm árum áður. Loks taldi um fjórðungur aðspurðra sig eiga mjög eða fremur mikla samleið með pjóðkirkjunni og var pað hlutfall nánast óbreytt frá pví fimm árum áđur. ${ }^{3}$ Ljóst er pví að margir tilheyra pjóðkirkjunni án pess að aðild peirra að henni standi föstum fótum í kenningu hennar og helgihaldi. Petta er vissulega ekki séríslenskt fyrirbæri heldur sameiginlegt einkenni á norrænni trúarmenningu. ${ }^{4}$

Fyrrgreindar tölur varpa ljósi á kvikt ástand og pær benda til að staða kirkjunnar geti fyrirstöðulítið tekið örum breytingum á næstu áratugum, til dæmis pannig að kirkjuaðildin hrapi hraðar hér á næstu tuttugu árum en gerst hefur frá aldamótum. Lútherska kirkjan verður pó áfram fjölmennasta kirkjudeild landsins um fyrirsjáanlega framtíð. Samt er líklegt að ekki verði ýkja langt í að félagatala hennar verði komin vel undir helming landsmanna. Pá gæti hlutfall peirra sem samsamar sig á marktækan máta með kirkjunni og trú hennar verið komið vel undir fimmtung og sterkar efasemdir pá verið teknar að vakna um hvort lútherska kirkjan geti talist pjóðkirkja Íslendinga öðruvísi en í sögulegri merkingu.

3 „Siðmennt. Lífsskoðanir Íslendinga og trú, nóvember 2015“, Siðmennt, bls. 4, 5, 7, 10, sótt 1. febrúar 2021 af https://www.sidmennt.is/media/ztjfk4jv/1\%C3\%ADfssko \% C3\% B0anir-\% C3\% ADslendinga-k\% C3\% B6nnun-si \% C3\% B0menntar-2015.pdf. „Siðmennt. Lífsskoðanir Íslendinga og trú, febrúar 2020“, Siðmennt, bls. 3, 7, 12, 16, sótt 1. febrúar 2021 af https://www.sidmennt.is/media/ mmed3 ggw/1\%C3\%ADfssko\%C3\%B0anir-\%C3\%ADslendinga-k\%C3\%B6nnun-si\%C3\%B0menntar-2020.pdf. Athygli vekur að Siðmennt hefur tvívegis á skömmu tímabili látið gera viðamiklar kannanir sem varpa ljósi á trúarlíf landsmanna. Pjóðkirkjan hefur á hinn bóginn ekki sýnt neina viðleitni til að greina stöðu sína eða starfsumhverfi á viðlíka hátt.

4 Pål Ketil Botvar, „Kristen tro i Norden. Privatisering og svekkelse av religiøse dogmer", Folkyrkor och religiös pluralism — den nordiska religiösa modellen, ritstjórar Göran Gustafsson og fleiri, Stokkhólmi: Verbum, 2000, bls. 74-96, hér bls. 88-91. Hjalti Hugason, „Að tilheyra án pess að trúa“, Kirkjublaðið.is, 10. desember 2020, sótt 1. febrúar 2021 af https://www.kirkjubladid.is/gestaglugginn/ad-tilheyra-anthess-ad-trua/. 
Prátt fyrir pær tvísýnu framtíðarhorfur íslensku pjóðkirkjunnar sem hér hefur verið drepið á má vera að próunin sem uppi er snerti fremur ytra byrði en dýpri lög trúarmenningarinnar. Viðamesta könnun sem gerð hefur verið á trúarlífi landsmanna var lögð fyrir 1986 og voru niðurstöður hennar kynntar fjórum árum síðar. Pá tilheyrðu heil 92 prósent landsmanna pjóðkirkjunni. Ekki er mögulegt að bera niðurstöður pessarar könnunar að öðru leyti beint saman við tölurnar frá 2020. Í eldri könnuninni taldi til að mynda aðeins priðjungur svarenda sig játa kristna trú. Skilningurinn á hvað í pví fælist hefur pví verið annar en í síðari könnuninni og samsvarar pessi hópur væntanlega peim sem játuðu hefðbundna kirkjulega trú 2020. Meira samræmi kemur fram í að á níunda áratugi tuttugustu aldar kváđust 40 prósent trúuð „á sinn eigin persónulega hátt. “5 Samræmist pað vel hlutfallstölum peirra sem töldu sig trúuð í yngri könnununum. Pá pótti könnunin frá níunda áratugnum leiða í ljós að porri pjóðarinnar iðkaði yfirborðslegt (e. extrinsic) trúarlíf og tæki mjög takmarkaðan pátt í starfi kirkjunnar. ${ }^{6}$ Minnihluti pjóðarinnar hefur bví líklega átt verulega samleið með pjóðkirkjunni fyrir 30 árum svipað og nú. Samsömun landsmanna með pjóðkirkjunni hefur pví tekið mun hægari breytingum en aðild peirra að henni og virðist raunar hafa verið fremur takmörkuð til langs tíma.?

Í pjóðkirkjunni er próun síðari ára pó litin alvarlegum augum og ber tíðum á góma í umræðum kirkjufólks sem leitar skýringa. ${ }^{8}$ Oft er pá vísað til biskupsmálsins svokallaða í lok aldarinnar sem leið, er Ólafur Skúlason (biskup 1989-1997) var sakaður um kynferðislega áreitni við hóp kvenna, en einnig ýmis önnur atvik er einstakir fulltrúar kirkjunnar hafa verið bornir ávirðingum eða eru taldir hafa brugðist trausti. Loks eru spenna, átök og deilur einkum í prestastétt tilfærðar í pessu sambandi. ${ }^{9}$ Pví kemur ekki á

5 Björn Björnsson og Pétur Pétursson, Trúarlif Íslendinga. Félagsfreðileg könnun, Ritröð Guðfræðistofnunar 3, Reykjavík: Háskóli Íslands, 1990, bls. 8, 204, 226.

6 Sama heimild, bls. 227.

7 Hjalti Hugason, „„,... úti á pekju pjóðlífsins“. Samband pjóðkirkju og pjóðar við upphaf 20. aldar“, Gliman sérrit 2/2010, bls. 97-125.

8 Hér er vísað til umræðu sem höfundur hefur oft verið vitni að og/eða tekið pátt í á ýmiss konar fundum og samkomum. Lítið hefur verið fjallað um vandann í rituðu máli.

9 Áhugavert er að deilur presta skuli álitnar vera áhrifavaldur í pessu sambandi par sem skautun í prestastétt hefur verið mun minni síðustu áratugi en var til að mynda á tímabilinu 1900 til um 1960 en pá stóðu yfir mikil átök ólíkra guðfræðistefna. Hlutfall peirra sem tilheyra pjóðkirkjunni lækkaði óvenjuhratt á tímabilinu 2005-2007 eða um rúm fimm prósentustig. Pá lækkaði pað óvenju mikið eða um 1,5\% 2010. Umræður um hjónaband samkynhneigðra stóðu sem hæst á tímabilinu og gæti pað 
óvart að kirkjufólk lítur oft svo á að hrakandi staða pjóðkirkjunnar í samfélaginu stafi af óánægju með kirkjustofnunina á landsvísu og/eða yfirstjórn kirkjunnar en að hún beinist ekki að starfi kirkjunnar í héraði, pað er úti í sóknum og prestaköllum landsins. Ekki liggja fyrir neinar kannanir sem styðja petta álit. Biskupsmálið og átök í prestastéttinni eru að sönnu líklegri til að vekja gagnrýni í garð kirkjustofnunarinnar og yfirstjórnar hennar en kirkjustarfs í söfnuðum landsins. Svo parf pó ekki að vera pegar einstakir prestar eru bornir sökum. Pá ber pess að gæta að sóknir kirkjunnar eru margar og ólíkar. Ekki er raunhæft að ganga út frá að í peim öllum ríki eintóm ánægja með starfið og pjónustuna eða í peim komi ekki upp aðstæður sem hafa áhrif á tengsl fólks við kirkjuna til hins verra. Pau skýru skil sem gengið er út frá milli kirkjustofnunarinnar og kirkjunnar í héraði kunna pví að fela í sér einföldun og að einhverju leyti skýrast af viðleitni peirra sem starfa úti í sóknunum til að vísa frá sér ábyrgð. Liggur kirkjustjórnin pá vel við höggi. Átök, deilur og persónulegar ávirðingar eru vissulega líklegar til að valda tímabundnum uppsveiflum ekki síst hvað tíðni úrsagna úr pjóðkirkjunni áhrærir. Pær eru á hinn bóginn síður til pess fallnar að varpa ljósi á hæggengari og stöðugri breytingar.

Í pessari grein verður leitað annarra og almennari skýringa á hrakandi stöðu pjóðkirkjunnar en að framan getur. Í stað pess að vísa til einstakra skýrt tímasetjanlegra atburða og/eða persóna og ávirðinga peirra verður horft til breyttrar pjóðfélagsgerðar sem og breyttra hlutverka kirkjunnar og embættismanna hennar í samfélaginu. Gengið verður út frá peim skilningi að sú breytta staða kirkjunnar í samfélaginu sem kemur ekki síst fram í hratt fallandi hlutfallstölu peirra sem tilheyra pjóðkirkjunni stafi öðru fremur af samfélagsbreytingum til langs tíma sem pjóðkirkjunni, arftaka meirihlutakirkjunnar í landinu — kapólsku miðaldakirkjunnar fyrir siðaskipti en síðar lúthersku ríkiskirkjunnar í löndum Danakonungs — hafi ekki heppnast að taka pátt í. Af peim sökum hafi verulegt misgengi myndast milli hennar og samfélagsins sem skýri að mestu hve hratt breytingarnar ganga nú fyrir sig.

hafa valdið einhverju um lækkunina. Рó parf pað ekki að hafa stafað af átökum um málið. Seinagangur og ráðaleysi gæti og hafa valdið miklu. Ef svo hefur verið hefur óánægja með pað beinst að kirkjustofnuninni og yfirstjórn hennar. Mest hefur hlutfallið í pjóðkirkjunni pó lækkað síðustu árin en á tímabilinu 2014-2020 féll pað um rúm 11 prósentustig. Torvelt virðist að benda á sértækar kirkjulegar skýringar á próuninni á peim tíma. „Mannfjöldi eftir trú og lífsskoðunarfélögum 1998-2020“, Hagstofa Íslands, sótt 1. febrúar 2021 af https://px.hagstofa.is/pxis/pxweb/is/Samfelag/Samfelag__menning_5_trufelog/MAN10001.px/table/tableViewLayout1/ ?rxid=6bd0ee91-d9d7-43b4-a5d2-9ea69d533ca8. 
Fyrr á tímum var kirkjan meginstoð samfélagslegra innviða og starf hennar samofið samfélagslífinu á flestum sviðum pess. Svo er ekki lengur. Nú er formlegt hlutverk hennar mun afmarkaðra og sértækara. Misgengið stafar meðal annars af pví að í kirkjunni búa ýmiss konar hefðir og venjur að trúarlegri, guðfræðilegri og sögulegri helgi og njóta par sterkari stöðu en á flestum sviðum öðrum í samfélaginu. Fjölmargt í stofnunargerð og sjálfskilningi pjóðkirkjunnar mótast pví enn í dag af aldagömlum aðstæðum en á ýmsum sviðum má greina hliðstæður og langtímasamhengi í sögu kirkjunnar sem nær allt fram til sîðustu tíma og varpar ljósi á nútímaaðstæður. Hér verður sérstaklega litið svo á að íslenska pjóðkirkjan hafi allt fram undir petta verið stofnunar-, „sveita-“, og prestakirkja og skýri pað að verulegu leyti framandleika hennar í nútímasamfélagi. Til að undirbyggja pessa skýringu verður stiklað á stóru um sögu íslensku kirkjunnar frá öndverðu og fram á pennan dag og par með leitast við að varpa ljósi á ríkjandi aðstæður í kirkjunni.

\section{Tvenns konar skýringar}

Fyrrgreindar tilraunir pjóðkirkjufólks til að skýra hrakandi stöðu kirkjunnar eru persónu- og atburðahverfar. Í pví eiga pær sammerkt með peim söguskilningi sem löngum hefur verið ríkjandi meðal pjóðarinnar og jafnvel í menntakerfinu pótt hann hafi fyrir nokkrum áratugum vikið fyrir félagslegri áherslum í fræðilegum sögurannsóknum og -ritum. Hér er litið svo á að fastheldni við gamlan söguskilning torveldi kirkjufólki að skilja og skýra pá próun sem uppi er varðandi breytta stöðu pjóðkirkjunnar og beini athyglinni frá pungvægari ástæðum. Petta er einkum bagalegt par sem líklegt er að kirkjan bregðist ekki við próuninni á raunhæfan og markvissan máta. Hér er litið svo á að frjórra sé að leita skýringa á hrakandi stöðu pjóðkirkjunnar í samfélaginu með hjálp samfélagshverfari söguskilnings líkum peim sem almennt er gengið út frá í nútímasagnfræði. Út frá pví sjónarhorni er skýringanna einkum að leita í breyttri pjóðfélagsgerð, fastheldni hvað varðar stofnunargerð pjóðkirkjunnar og ekki síst fækkandi formlegum hlutverkum hennar í samfélaginu.

Á síðari tímum, einkum á fyrstu áratugum tuttugustu aldar og svo í kjölfar síðari heimsstyrjaldarinnar, urðu sem kunnugt er stórfelldari breytingar á íslenska samfélaginu en orðið höfðu í margar aldir par á undan. Í stað sveitasamfélags í hægfara breytingaferli sem auk pess einkenndist af fámenni, dreifbýli, fábreyttum atvinnuháttum, lítilli tæknivæðingu, einföldum innviðum og takmarkaðri sérhæfingu er nú komið margbrotið péttbýlissam- 
félag í örum breytingum með péttriðið net innviða sem kallar á öra endurskoðun á verkaskiptingu og hlutverkum bæði einstakra samfélagsstofnana og starfsstétta. Helstu afleiðingum pessarar breytingar á kirkjulega sviðinu hefur verið lýst svo að próunin hafi legið frá „trúarmenningu til trúarsannfæringar".$^{10}$ En sú breyting er viðamikill páttur í nútímavæðingu vestrænna samfélaga og hefur kallað fram trúarsögulegar aðstæður af sérstöku tagi sem ekki síst eru taldar einkenna Norðurlönd. Með trúarmenningu er pá átt við samfélagsaðstæður sem einkenndust af pví að menningarmótun kirkjunnar var víðtæk og óumdeild og að merki trúarinnar voru hvarvetna sýnileg á yfirborði samfélagsins. Trúarlíf og annir daglegs lífs ófust og saman á margvíslegan máta auk pess sem kirkjan gegndi margpættum og mikilvægum hlutverkum á fjölmörgum sviðum samfélagsins auk pess sem nú á dögum er litið á sem trúarlegt svið. ${ }^{11}$

Hefðbundnar túlkanir á trúarsögulegum afleiðingum nútímavæðingar er að par vegi sekúlarísering eða afhelgun hvað pyngst. Hún felst í að áhrifasvæði kirkjunnar og/eða „hins trúarlega“ prengist og aðgreinist frá öðrum sviðum samfélags og menningar og leysi pað upp hina hefðbundnu trúarmenningu. Á síðari áratugum hafa viðhorf breyst í pessu efni og áhersla verið lögð á að afhelgunin próist mishratt og á mismunandi vegu eftir pví hvort um samfélagið, trúarstofnunina (kirkjur og trúfélög) eða hugarheim einstaklinga er að ræða. Nútímavæðingin er pví margbrotnari en löngum hefur verið látið að liggja og nú er litið svo á að vaxandi trúarleg einstaklingshyggja, sem hér framar var nefnd „trúarsannfæring“, hafi vegið pungt við hlið sekúlaríseringarinnar auk fjölhyggju par sem aðstæður bjóða upp á mismunandi túlkunarramma sem sóttir eru til ólíkra kirkjudeilda eða trúarbragða. Löngum var talið að veraldarvæðing af pessu tagi hafi gengið mun lengra á Norðurlöndum en annars staðar og kallað fram sérstakar trúarsögulegar aðstæður sem einkennast af sterkri veraldarhyggju. Í seinni tíð hefur verið dregin upp fínkembdari mynd. Nú er litið svo á að á Norðurlöndum gæti tiltölulega mikillar trúarlegrar einstaklings- og skynsemishyggju en pó takmarkaðrar fjölhyggju, að prestastéttin hafi sterka stöðu innan trúarstofnunarinnar, að lítil pátttaka sé í kirkjulegu starfi pótt mikillar fastheldni gæti varðandi kirkjustofnunina sem kemur fram í að Norðurlandabúar eru ólík-

10 Loftur Guttormsson, Frá siðaskiptum til upplýsingar, Kristni á Íslandi III, ritstjóri Hjalti Hugason, Reykjavík: Alpingi, 2000, bls. 357-359.

11 Nefna má sjóferðabænir og aðrar bænir sem tengdust ferðum eða mikilvægum verkum. Hjalti Hugason, „Kristnir trúarhættir“, Ílensk Pjóðmenning V, ritstjóri Frosti F. Jóhannsson, Reykjavík: Pjóðsaga, 1988, bls. 180-183, 313-314, 336-337. 
legir til að skipta um kirkjudeild eða trúarbrögð og/eða taka sér stöðu utan peirra hvað sem persónulegri sannfæringu líður. Sjálfsmynd Norðurlandabúa virðist enda fela í sér að hinn dæmigerði Norðurlandabúi sé kristinn og jafnvel lútherskur. ${ }^{12}$ Hér á landi hófst próun í pessa veru ekki að marki fyrr en líða tók á nítjándu öld og var pað síðar en í nálægum löndum.

Eitt af einkennum trúarmenningarinnar var að til pess var ætlast að almenningur samsamaði sig trúarkenningum og siðalærdómum kirkjunnar auk pess að taka pátt í guðspjónustu hennar og annarri fyrirskipaðri trúariðkun. Persónuleg trúarsannfæring og -afstaða einstaklinga hvarf á hinn bóginn í skuggann og trúfrelsi var ekki til staðar enda hefði pað rofið pá samstöðu í samfélaginu sem trúarmenningin gekk út á. ${ }^{13}$ Hér var krafan um trúarlega samstöðu fyrst sett fram í kristinrétti forna, öðru nafni Kristinna laga pætti Grágásar, en hann hefur að geyma veraldlega löggjöf sem viðtekin var á alpingi. Í honum var kveðið á um skyldur almennings varðandi kristnihald en líka skyldur kirkjunnar eða embættismanna hennar í veraldlega samfélaginu. ${ }^{14}$ Má rekja ákvæðin til tímabilsins $1122-1133 .{ }^{15}$ Í upphafi páttarins segir: „Á dögum feðra vorra voru pau lög sett að allir menn skulu kristnir

12 Prátt fyrir að Norðurlönd beri sterk sameiginleg einkenni sem greina pau frá til að mynda Bretlandseyjum, löndum sunnan- og austanverðrar Evrópu og BNA gætir ýmissa blæbrigða milli peirra sem og dreifbýlla og péttbýlla svæða í einstökum norrænum löndum. Pål Ketil Botvar, „Kristen tro i Norden“, bls. 74-96. Susan Sundback, „Medlemskap i de lutherska kyrkorna i Norden“, Folkkyrkor och religiös pluralism — den nordiska religiösa modellen, Stokkhólmi: Verbum, 2000, bls. 34-73. Sjá og Ole Riis, „Den europæiske integrations udfordring til danskernes religiøse identitet“, Kirken og Europa, ritstjóri Jakob Balling, Árósum: Aarhus universitetsforlag, 2000, bls. 158-198.

13 Sjá Hrafnkell Lárusson, Lýðreði í mótun. Félagastarf, fjölmiðlun og pátttaka almennings 1874-1915, Reykjavík: Háskóli Íslands, 2021, bls. 46. (Óútgefin doktorsritgerð í sagnfræði við Háskóla Íslands, aðgengileg á vefnum Opin vísindi: https://opinvisindi. is/handle/20.500.11815/2475).

14 Skyldur presta við samfélagið í upphafi voru einkum að tilkynna á leiðarpingum að hausti hvar fastur dvalarstaður peirra yrði næsta árið. Pá máttu peir ekki yfirgefa petta lögheimili sitt án pess að hafa meðferðis pað sem peir purftu til að geta veitt neyðarpjónustu. Var pá einkum átt við barnsskírn sem oft gat borið brátt að meðan ungbarnadauði var mikill. Grágás. Lagasafn islenska pjóoveldisins, Gunnar Karlsson, Kristján Sveinsson og Mörður Árnason sáu um útgáfuna, Reykjavík: Mál og menning, 1992, bls. 2, 13, 17, 194, 438.

15 Grágás, bls. 34. „Inngangur“, Grágás. Lagasafn íslenska pjóðveldisins, Gunnar Karlsson, Kristján Sveinsson og Mörður Árnason sáu um útgáfuna, Reykjavík: Mál og menning, 1992, bls. ix-xxxiii, hér bls. x-xi. Ákvæðin eru meðal annars varðveitt í handritunum Konungsbók og Staðarhólsbók sem skráð voru á tímabilinu frá um 1250 til um 1270. „Inngangur [Grágás]“, bls. xv-xvii, xix. 
vera á landi hér og trúa á einn Guð, föður og son og anda helgan. "16 Aftar í pættinum er ákvæðið útfært nánar:

Menn skulu trúa á Guð einn og á helga menn til árnaðarorðs sér, og blóta eigi heiðnar vættir. Pá blótar maður heiðnar vættir er hann signar fé sitt öðrum en Guði og helgum mönnum hans. Ef maður blótar heiðnar vættir, og varðar pað fjörbaugsgarð, [...]. ${ }^{17}$

Jafnframt var bannað að fara með galdur, fjölkynngi eða fordæðuskap og hindurvitni. ${ }^{18}$ Hér er um skilyrðislausari kröfu að ræða en fram kom í kristnitökulögunum eins og peim er lýst í Íslendingabók en samkvæmt peim mátti blóta á laun. ${ }^{19}$ Skilgreining hinnar lögbundnu trúar tók ýmsum breytingum í tímans rás. Sú róttækasta varð í kjölfar siðaskiptanna pegar játningagrunnur kirkjunnar var skilgreindur í konungalögum Friðriks III (1665) og dönskum lögum Kristjáns V (1683). Eftir pað skyldi trúareining samfélagsins hvíla á fornkirkjulegu játningunum premur, Postullegu trúarjátningunni, Níkeujátningunni og Apanasíusarjátningunni auk Ágsborgarjátningarinnar, Fræða Lúthers hinna minni og Ritningarinnar. ${ }^{20}$ Eru pessi ákvæði enn í gildi hvað pjóðkirkjuna áhrærir.

Á nýöld og pá einkum tímabilinu eftir upplýsinguna og píetismann fluttist áherslan í vestrænum nútímasamfélögum frá samfélagsheildinni og hagsmunum hennar, eins og peir voru skilgreindir af valdhöfum, yfir á frelsi hinna ýmsu samfélagshópa og loks einstaklinga. Pá varð pað mikilvæg krafa að hver og einn væri frjáls hugsana sinna, samvisku og trúar. Fyrsta skrefið í pá átt var stigið hér með stjórnarskránni um innanríkismál landsins 1874 er veitti trúfélögum peirra sem játuðu trú á guð frelsi til að pjóna honum með peim hætti sem best ætti við sannfæringu hvers og eins. ${ }^{21}$ Ekki var að fullu ljóst fyrr en eftir stjórnarskrárbreytingu 1915 að heimilt væri að standa

16 Grágás, bls. 1.

17 Sama rit, bls. 19.

18 Sama rit, sama stað.

19 Par var líka gerð undanpága varðandi barnaútburð og hrossakjötsát. „Íslendingabók“, Íslenzk fornrit I, Jakob Benediktsson gaf út, Reykjavík: Hið íslenzka fornritafélag, 1968, bls. 3-28, hér bls. 17. Grágás, bls. 32, 34, 44.

20 Hjalti Hugason, „Pjóðkirkja og trúfrelsi. Inntak og merking trúmálabálks stjórnarskrárinnar ásamt breytingartillögum“, Ritið 2/2011, bls. 151-181, hér bls. 156.

21 „Stjórnarskrá um hin sjerstaklegu málefni Íslands nr. 1, 5. janúar 1874 (46. gr.)“, Stjórnarráðið, sótt 4. febrúar 2021 af https://www.stjornarradid.is/media/forsaetisraduneyti-media/media/stjornarskra/1874_stjornarskra.pdf. 
utan allra trúfélaga. ${ }^{22}$ Síðar færðist áherslan enn frekar frá trúfélögunum yfir á einstaklingana eins og kemur vel fram í Mannréttindasáttmála Evrópu sem lögfestur var hér 1994. ${ }^{23}$ Pað var bví ekki fyrr en á tuttugustu öld sem trúarsannfæring einstaklinganna tók par með við sem grunnforsenda í trúarefnum í stað trúarmenningar og samsömunar áður.

Pessi próun, sem að sönnu tók langan tíma, hafði í för með sér gjörbreytta stöðu pjóðkirkjunnar og mótar mjög pau hlutverk sem hún gegnir nú í samfélaginu. Hið augljósasta er að stofnun sem áður hafði myndað hornstein peirrar samfélagslegu einingar sem keppt var að og hvíldi á trúarlegum grunni missti petta sameiningarhlutverk sitt. Samfélagseiningin skyldi eftirleiðis hvíla á veraldlegum, vestrænum gildum, svo sem frelsi, lýðræði, jafnræði og mannréttindum. Próunin skapaði líka svigrúm fyrir sívaxandi einstaklingshyggju í trúarlegum og menningarlegum efnum. Fjölhyggju gætir á hinn bóginn síður sökum pess hve samtoga samfélagið var allt fram á síðustu áratugi.

Hér er litið svo á að pessi próun frá trúarmenningu til trúfrelsis og eintaklingshyggju ráði hvað mestu um pá próun sem tölfræðin í upphafi greinarinnar varpar ljósi á. Einstakar persónur og atburðir sem kirkjulega skýringarlíkanið vísar til hrekkur par mun skemur til.

\section{Frá stofnunarkirkju til trúfélags}

Líta má svo á að samkvæmt kapólskri kenningu sé kirkjan hjálpræðisstofnun sem miðlar náð Guðs til manna með hjálp sakramenta sinna og embætta en að hún sé fremur trúarsamfélag eða söfnuður að lútherskum skilningi. Hér er pó fremur um mismunandi kirkjuguðfræði (e. ecclesiology) að ræða en að munurinn komi endilega fram í stofnunargerð eða starfsháttum einstakra kirkna. Óháð pessum guðfræðilegu túlkunum hefur kirkjan enda tekið á sig ýmsar stofnunarlegar myndir í tímans rás og axlað margháttuð félagsog menningarleg hlutverk par sem stofnunargerð kirkjunnar hverju sinni hefur oft vegið pyngra en kirkjudeild, kapólsk eða lúthersk. Siðbótin sem slík markaði til að mynda ekki ótvíræð tímamót hvað varðar stöðu kirkjunnar í íslenska samfélaginu. ${ }^{24}$ Samfélagsgerðin, réttarstaða kirkjunnar sem

22 „Stjórnarskrá um hin sjerstaklegu málefni Íslands uppfærð með öllum breytingum til og með 1915 (47. gr.)“, Stjórnarráðið, sótt 3. maí 2021 af https://www.stjornarradid.is/media/forsaetisraduneyti-media/media/stjornarskra/1915_svo_breytt.pdf.

23 „Lög um mannréttindasáttmála Evrópu nr. 62/1994 (9. gr.)“, Alpingi, sótt 4. febrúar 2021 af https://www.althingi.is/lagas/151a/1994062.html.

24 Hér er orðið siðbót notað um guðfræðilega gagnrýni Lúthers á miðaldakirkjuna og 
og pað svigrúm sem hún naut gagnvart veraldlegum valdhöfum — síðar ríkisvaldinu — virðist ekki síður hafa skipt máli varðandi pær breytingar sem pó urðu í kjölfarið.

Um miðja síðustu öld kynnti Björn Karel Pórólfsson áhugavert yfirlit yfir próun íslensku kirkjunnar með tilliti til réttarstöðu og tengsla við veraldarvaldið. Hann skipti sögunni upp í tímabil goðakirkju í öndverðu, páfakirkju frá lögtöku kristinréttar Árna Porlákssonar á 13. öld, landskirkju frá siðaskiptum, ríkiskirkju frá miðri átjándu öld og loks pjóðkirkju eftir 1874. ${ }^{25}$ Ápekk tímabilaskipting hefur vissulega oft verið viðhöfð pótt önnur heiti hafi verið notuð. ${ }^{26}$ Mörgum hefur pó yfirsést skeið landskirkjunnar og álitið að hér hafi ríkiskirkja komist á strax með siðaskiptunum..$^{27}$ Á tímabilinu frá miðri sextándu öld til miðrar átjándu aldar hélt íslenska kirkjan samt umtalsverðu frjálsræði enda hafði danska ríkið enn ekki náð að innlima landið að fullu í stjórnkerfi sitt. Prátt fyrir að brýnustu breytingar væru að sönnu gerðar á kirkju og kristnihaldi við lögfestingu kirkjuskipanar Kristjáns III hélst líka umtalsvert samhengi við miðaldakristnina að ýmsu leyti. ${ }^{28}$ Réttlætir petta að rætt sé um sérstakt tímabil landskirkju.

Pessi stofnunarsögulegu tímabil endurspegla tæpast breytingar hvað hlutverk kirkjunnar áhrærir. Veldur par miklu um hve stöðug samfélagsgerðin í landinu var. Pá skiptir máli að allt frá tilkomu páfakirkjunnar fram yfir setningu stjórnarskrárinnar 1874 var kirkjan fyrst og fremst stofnun sem starfaði í vaxandi tengslum við alpjóðlegu miðaldakirkjuna um daga „páfakirkjunnar" en í auknum tengslum við sívaxandi ríkisvald eftir siðaskipti uns einveldi komst á eftir miðja sautjándu öld. Í kjölfar pess að pjóðkirkja komst hér á hófst á hinn bóginn hægfara umbreytingarferli er kirkjan tók í vaxandi mæli á sig mynd trúfélags. Um svipað leyti hófst svo nútímavæðing

pær breytingar sem hann beitti sér fyrir í kirkjunni og miðuðu meðal annars að pví að jafna stöðu leikra og lærðra.

25 Björn Karel Pórólfsson, „Inngangur“, Biskupsskjalasafn, Skrár Pjóðskjalasafns III, Reykjavík: [án útg.], 1956, bls. 7-76, hér bls. 66-68.

26 Goðakirkjan hefur til að mynda verið kölluð landskirkja („Landeskirkche“) og höfðingjakirkja. Bjarni Sigurðsson, Geschichte und Gegenwartsgestalt des isländischen Kirchenrechts, Europäische Hochschulschriften II: 524, Frankfurt: Peter Lang, 1986, bls. 253. (Doktorsritgerð). Hjalti Hugason, Frumkristni og upphaf kirkju, Kristni á Íslandi I, ritstjóri Hjalti Hugason, Reykjavík: Alpingi, 2000, bls. 287.

27 Sjá pó Loftur Guttormsson, Frá siðaskiptum til upplýsingar, bls. 301, 357-358.

28 Sjá Hjalti Hugason, „Hvenær urðum við lúthersk og hvenær hættum við að vera pað? Leit að viðmiðum í siðaskiptasögu Íslendinga“, Ritið 2/2016, bls. 70-107, hér bls. 100-105. Hjalti Hugason, „Seigfljótandi siðaskipti. Viðhorf og staðalmyndir í siðaskiptarannsóknum“, Ritið 1/2018, bls. 165-197. 
samfélagsins. Olli hvort tveggja margháttuðum breytingum á hlutverkum kirkjunnar.

Mikils misgengis gætti í próun pjóðkirkjunnar í átt frá stofnun til (trú-) félags eftir pví hvort um var að ræða kirkjuna á landsvísu, pað er yfirstjórn hennar, eða úti í héruðum, í prófastsdæmum, prestaköllum og einkum sóknum. Kann pað að valda nokkru um pá spennu sem enn gætir milli pessara tveggja megingreina kirkjunnar og drepið var á í upphafi. Fyrsta skrefið í pessu breytingaferli var stigið með lögum um stjórn safnaðarmála 1880. Samkvæmt peim átti að kjósa priggja manna sóknarnefnd í hverjum söfnuði til að veita málefnum hans forstöðu ásamt sóknarpresti. Nefndin átti auk pess að vera prestinum til aðstoðar í að efla góða reglu, siðsemi og friðsemd í söfnuðinum og á heimilum. Pá átti hún að aðstoða við uppfræðslu ungmenna og vera meðhjálparar prestsins við guðspjónustuna. Ennfremur var heimilt að hún tæki við fjárráðum safnaðarins og pá einnig umsjón sóknarkirkjunnar. Loks hafði nefndin tillögurétt við val á presti. Auk pess átti að kjósa fulltrúa safnaða til að sitja í héraðsnefnd í hverju prófastsdæmi ásamt prestum og prófasti. Hún átti að útkljá sameiginleg mál sóknanna og fjalla um ýmis almenn kirkjumál á svokölluðum héraðsfundum. Sérstaklega áttu héraðsnefndirnar pó að upplýsa prófast um hvernig prestar og sóknarnefndir ræktu köllun sína og pá einkum uppfræðslu barna. ${ }^{29}$ Мeð lögunum var almenningi í fyrsta sinn veitt aðkoma að starfi kirkjunnar pótt sjálfstæð hlutverk sóknarnefnda væru fá til að byrja með. Tveimur árum síðar voru svo sampykkt lög um að söfnuðir gætu óskað eftir að taka við kirkjubyggingum af fyrri forráðamönnum, kirkjueigendum eða prestum á prestssetrum, og annast eftirleiðis fjárhald peirra, rekstur, viðhald og endurbyggingu. ${ }^{30}$ Par með öðluðust íbúar hverrar sóknar í fyrsta sinn sameiginleg réttindi og skyldur gagnvart kirkju sinni umfram pað sem sóknarnefndunum var áður falið. 1886 var söfnuðum svo í fyrsta sinn veitt bein aðkoma að vali á prestum og veitingu prestakalla. ${ }^{31}$ Fóru pessi áhrif stigvaxandi uns teknar

29 Stjórnartíðindi 1880 A, bls. 28-31 (1. nr. 5/1880). Magnús Jónsson, Alpingi og kirkjumálin 1845-1943, Reykjavík: Alpingissögunefnd, 1952, bls. 25-26. Bjarni Sigurðsson, Geschichte und Gegenwartsgestalt des isländischen Kirchenrechts, bls. 234.

30 Stjórnartíðindi 1882 A, bls. 76-79 (1. nr. 13/1882). Magnús Jónsson, Alpingi og kirkjumálin, bls. 60 .

31 Um var að ræða almennar kosningar milli priggja úr hópi umsækjenda (tveggja væru umsækjendur aðeins prír) er landshöfðingi hafði valið í samráði við biskup. Stjórnartíðindi 1886 A, bls. 2-7 (1. nr.1/1886). Magnús Jónsson, Alpingi og kirkjumálin, bls. 39-40. Bjarni Sigurðsson, Geschichte und Gegenwartsgestalt des isländischen Kirchenrechts, bls. 236-237. 
voru upp almennar prestskosningar sem viðhafðar voru á tímabilinu 19151987.32 Próun hreinræktaðrar kirkjustofnunar í átt að félögum og bá á sviði safnaðanna hófst sem sé á níunda áratugi nítjándu aldar. Tók pá jafnframt að örla á lýðræðisvæðingu í kirkjunni í héraði pótt hægt miðaði lengi framan af.

Á níunda og tíunda áratugi nítjándu aldar voru stofnaðir nokkrir evangelísk-lútherskir fríkirkjusöfnuðir í landinu. Peir byggðu í meginatriðum á sama játningagrunni og pjóðkirkjan en störfuðu á grundvelli laga um utanpjóðkirkjumenn frá 1886. Tilkoma pessara safnaða varpaði skýru ljósi á eðli pjóðkirkjunnar sem stofnunar. Fulltrúar hennar beittu sér til dæmis fyrir að gjaldfrelsi fríkirkjufólks gagnvart pjóðkirkjunni gilti pví aðeins að pað hefði sagt sig úr pjóðkirkju- og í fríkirkjusöfnuð fyrir fardaga ár hvert, pá féll gjaldfrelsi pess niður ef pað flutti út fyrir skilgreint starfssvæði fríkirkjusafnaðarins pótt pað stæði áfram utan pjóðkirkju og eins ef fríkirkjusöfnuður naut ekki pjónustu prests eða forstöðumanns er hlotið hafði konungsstaðfestingu jafnvel pótt um tímabundið hlé væri að ræða. Fríkirkjusöfnuðirnir störfuðu aftur á móti á svipuðum grunni og hver önnur frjáls félagasamtök. ${ }^{33}$

Upp úr 1890 hófst umræða um að auka pyrfti sjálfstæði pjóðkirkjunnar gagnvart ríkisvaldinu og sjálfræði hennar í eigin málum og pá með pátttöku kjörinna fulltrúa safnaðanna á kirkjupingi. ${ }^{34}$ Ekkert miðaði pó í pessa átt fyrr en kirkjuráð var stofnað 1931. Í pví sátu biskup auk fjögurra kjörinna fulltrúa, tveggja guðfræðinga sem kosnir voru af prestum og kennurum guðfræðideildar Háskóla Íslands og tveimur „leikum“ fulltrúum kjörnum af héraðsfundum. Hlutverk pess var að vinna að eflingu íslenskrar kristni og styðja að trúar- og menningaráhrifum pjóðkirkjunnar. Ákvörðunarvaldi pess voru pó settar pröngar skorður og náði pað aðeins til guðspjónustu og helgisiða. ${ }^{35} 1957$ tók svo loks kirkjuping til starfa. Рað tók við hlutverkum

32 Stjórnartíðindi, 1987 A:I, bls. 68-71 (1. nr. 44/1987). Magnús Jónsson, Alpingi og kirkjumálin, bls. 93-94. Bjarni Sigurðsson, Geschichte und Gegenwartsgestalt des isländischen Kirchenrechts, bls. 181-190. Val á prestum og veiting prestakalla hefur reynst flókið úrlausnarefni og tekið örum breytingum síðustu áratugi. Leitast hefur verið við að samræma ólík sjónarmið: köllunarrétt safnaða í lútherskum anda og fagleg viðmið par sem tekið er tillit til menntunar og reynslu umsækjenda. Parna takast á guðfræðileg og stofnunarleg eða fagleg sjónarmið.

33 Byggt á gögnum úr óbirtu rannsóknarverkefni höfundar „Trúfrelsi í framkvæmd 1874-1915“.

34 Magnús Jónsson, Alpingi og kirkjumálin, bls. 28-29. Hjalti Hugason, „Próun sjálfstæðrar pjóðkirkju á öndverðri 20. öld. Fyrstu tilraunir til að koma á kirkjupingi á Íslandi“, Ritröð Guðfreðistofnunar 31/2010, bls. 73-104.

35 Stjórnartiððindi 1931 A, bls. 30-31 (1. nr. 21/1931). Magnús Jónsson, Alpingi og kirkjumálin, bls. 113-114. Bjarni Sigurðsson, Geschichte und Gegenwartsgestalt des isländiscben Kirchenrechts, bls. 296-297. 
kirkjuráðs sem varð pá framkvæmdanefnd kirkjupings sem undirbjó mál sem lögð voru fyrir pingið og aðstoðaði biskup við að framkvæma sampykktir pess. ${ }^{36}$ Samkvæmt lögum um stöðu, stjórn og starfshætti pjóðkirkjunnar frá 1997 (svokölluðum pjóðkirkjulögum) sem giltu til skamms tíma er kirkjuping enn sem komið er skipað 29 kjörnum fulltrúum, par af 17 óvígðum og fer pað með æðsta vald í málefnum pjóðkirkjunnar nema lög kveði á um annað. ${ }^{37}$ Með kirkjuráði og kirkjupingi fékk almenningur í pjóðkirkjunni nokkra aðild að yfirstjórn hennar og stefnumörkun. Lýðræðið í kirkjunni á landsvísu er pó hreinræktað fulltrúalýðræði par sem aðeins lítill minnihluti kirkjufólks, pað er fulltrúar í sóknarnefndum, nýtur kosningaréttar við kirkjupingskosningar. ${ }^{38}$

Með setningu pjóðkirkjulaganna 1997 urðu loks pau straumhvörf í próun pjóðkirkjunnar að hún var í fyrsta sinn skilgreind sem trúfélag í lögum. ${ }^{39}$ Deila má um hvort lögin samræmist peirri skilgreiningu eða viðhaldi pvert á móti stofnunarlegu eðli kirkjunnar. Með nýjum lögum um pjóðkirkjuna sem öðluðust gildi 1. júlí 2021 er áfram stefnt í átt að trúfélagi með mun einfaldari lagaumgjörð. ${ }^{40}$

Af pví sem hér hefur verið rakið er ljóst að próun pjóðkirkjunnar í átt frá stofnunarkirkju að trúfélagi hófst ekki fyrr en undir lok nítjándu aldar og stendur enn yfir. Allar guðfræðilegar forsendur breytingarinnar hafa pó verið til staðar allt frá siðbót eins og vikið var að í upphafi kaflans.

36 Stjórnartíðindi 1957 A, bls. 155-157 (1. nr. 43/1957). Bjarni Sigurðsson, Geschichte und Gegenwartsgestalt des isländischen Kirchenrechts, bls. 291-298. „Starfsreglur um kjör til kirkjupings nr. 1075/2017 sbr. starfsreglur 1114/2018 (1. gr.)“, Kirkjan, sótt 11. febrúar 2021 af https://kirkjan.is/library/Files/Starfsreglur/Starfsreglur\%20 um\%20kjör\%20til\%20kirkjupings\%20nr.\%201075-2017,\%20sbr.\%201114-2018. pdf.

37 Valdi kirkjupings eru einkum takmörk sett pegar um kenningu, helgisiði og agavald er að ræða. „Lög um stöðu, stjórn og starfshætti pjóðkirkjunnar nr 78/1997 (20. gr.)“, Alpingi, sótt 5. febrúar 2021, af https://www.althingi.is/lagas/nuna/1997078. html.

38 „Starfsreglur um kjör til kirkjupings nr. 1075/2017 (4. gr.)“, Kirkjan, sótt 3. maí 2021 af https://kirkjan.is/library/Files/Starfsreglur/Starfsreglur\%20um\%20kjör\%20 til\%20kirkjupings\%20nr.\%201075-2017.pdf.

39 Í 1. mgr. 1. gr. laganna er pjóðkirkjan skilgreind sem „[...] sjálfstætt trúfélag á evangelísk-lútherskum grunni“. „Lög um stöðu, stjórn og starfshætti pjóðkirkjunnar nr 78/1997“, Alpingi, sótt 5. febrúar 2021 af https://www.althingi.is/lagas/ nuna/1997078.html.

40 „Lög um pjóðkirkjuna“, Alpingi, sótt 28. júní 2021 af https://www.althingi.is/altext/ 151/s/1806.html. Frumvarpið skiptist í 13. gr. sem er mikil einföldun miðað við 64. gr. í núgildandi lögum. 


\section{Frá „sveitakirkju“ til „péttbýliskirkju“}

Tíðum er torvelt að greina milli hlutverka kirkjunnar annars vegar og presta hennar hins vegar. Í pessari grein verður pví ekki leitast við að greina skýrt par á milli. Рað skýrir líka að umfjöllun um presta verður nokkuð fyrirferðarmikil hér á eftir. Í kapólskum sið stafar samruni presta og kirkju einkum af peirri miklu sérstöðu sem prestar hafa par sökum vígslu sinnar og kennivalds. Í lútherskum sið hefur gerð samfélagsins og stofnunargerð kirkjunnar á hinn bóginn vegið pyngra. Heilt yfir breyttu siðaskiptin pví litlu um stöðu prestanna einkum sökum pess að verulegar samfélagsbreytingar voru ekki hafnar hér á sextándu öld. Olli kyrrstaðan pví að prestar héldu sérstöðu sinni í kirkjunni og raunar samfélaginu lengur en siðbótin og lúthersk guðfræði gaf tilefni til. ${ }^{41}$ Greinir próunin hér á landi sig frá pví sem gerðist í flestum nálægum löndum par sem péttbýlismyndun og aðrar pjóðfélagsbreytingar voru fyrr á ferðinni. Til að varpa ljósi á petta verður í pessum kafla greint á milli tvenns konar kirkjuafbrigða með tilliti til mismunandi starfshátta sem viðhafðir eru innan hvors um sig. Heitin í yfirskrift kaflans eru pví notuð í yfirfærðri merkingu. „Sveitakirkja“ á við kirkju sem einkennist af fábreyttum starfsháttum sem mótuðust í sveitasamfélagi fyrri alda. „Péttbýliskirkja“ lýsir aftur á móti kirkju sem beitir fjölpættum starfsháttum sem taka mið af margbrotnu nútímasamfélagi. Í pessu sambandi skiptir aftur á móti ekki máli hvert ytra starfsumhverfi kirkjunnar er, sveit eða borg. ${ }^{42}$

Hér á landi starfaði í raun „sveitakirkja“ langt fram eftir tuttugustu öld en starf kirkju af pví tagi einskorðaðist við guðspjónustur á helgum dögum sem prestar önnuðust og helgiathafnir á ævihátíðum einstaklinga og fjölskyldna sem löngum hafa verið nefndar „aukaverk“ presta. ${ }^{43}$ Auk pess önnuðust prestar margháttað eftirlit einkum í árlegum húsvitjunum sínum. ${ }^{44}$ Eðli máls

41 Gunnar Kristjánsson, „Marteinn Lúther. Maður orðsins“, Marteinn Lúther. Úrval rita I, ritstjórar Arnfríður Guðmundsdóttir, Gunnar J. Gunnarsson og Sigurjón Árni Eyjólfsson, Reykjavík: Nefnd um fimm alda minningu siðbótarinnar, Skálholtsútgáfan, 2017, bls. 11-29, hér bls. 15-16.

42 Um próun „péttbýliskirkjunnar“ á Íslandi sjá Steinunn Arnprúður Björnsdóttir, „The Making of a City Church. Change in Taxation and Its Effect on Parish Work and the Role of Pastors", Nordic Fournal of Religion and Society 2/2017, bls. 153-170.

43 Hjalti Hugason, „Séra Pétur Sigurgeirsson“, Andvari LXI/2019, bls. 9-86, hér bls. 9-10.

44 Við húsvitjanir var litið eftir trúfræðslu og húsaga á heimilum en einnig almennari atriðum eins og lestrarkunnáttu og heilbrigðisástandi auk pess sem tekið var manntal. Hjalti Hugason, „Kristnir trúarhættir“, bls. 289-292. 1880 var aukið við eftirlitshlutverk presta. Auk pess að prófa kunnáttu í lestri og kristnum fræðum áttu 
samkvæmt er aftur á móti örðugt að ákvarða að hve miklu leyti sálgæsla var stunduð í íslensku „,sveitakirkjunni““. ${ }^{45}$ „Sveitakirkjan“ eða starf hennar fólst pví einkum í athöfnum á hátíðum og helgidögum. ${ }^{46}$ Í annan tíma birtist kirkjan nær einvörðungu í guðshúsunum sem voru pó lengi ekki sérhæfð og lokuð í sama mæli og síðar varð. ${ }^{47}$ Aðrir sem komu að starfi kirkjunnar gegndu hlutverkum sínum einkum sem „meðhjálparar“ prestanna. ${ }^{48} \mathrm{Um}$ safnaðarstarf í nútímamerkingu var pví ekki að ræða í „sveitakirkjunni“.

Péttbýli myndaðist hér fyrst í Reykjavík og dómkirkjupresturinn par varð pví fyrsti péttbýlisprestur landsins í bókstaflegum skilningi (frá pví um 1800). Af pessu leiðir ekki að „péttbýliskirkja“ hafi par með tekið við af „sveitakirkjunni“ í höfuðstaðnum. Á pví varð pvert á móti langur dráttur en höfundur pessarar greinar hefur fært rök fyrir að „péttbýliskirkja“ hafi komist einna fyrst á norður á Akureyri um miðbik tuttugustu aldar. ${ }^{49}$ Einkenni „péttbýliskirkju“ eru að starfsemi hennar einskorðast ekki við helgihald og „aukaverk“ presta heldur felst pað í fjölpættri félagslegri starfsemi. ${ }^{50}$ Hún kom í upphafi einkum fram í félagsstarfi meðal barna og unglinga en líta má svo á að rætur pess liggi í skírnarfæðslu (katekumenat úr gr. og lat.) kirkjunnar. Pá hófst og ýmiss konar félags- og menningarstarf meðal fullorðinna sem skoða má sem framhald af boðunarstarfi kirkjunnar eða predikuninni og loks starf meðal aldraðra. Á peim vettvangi haslaði kirkjan sér völl á sviði félags- og velferðarpjónustu á grundvelli kærleikspjónustuhlutverks kristinnar kirkju (gr. diakonia). Pegar kirkjan með pessum hætti færði út kvíarnar og fjölbreytt safnaðarlíf bættist við helgihaldið einskorðaðist starfið ekki lengur við

prestar nú að kanna kunnáttu barna í skrift og reikningi. Stjórnartíðindi 1880 A, bls. 6-9 (1. nr. 2/1880).

45 Sjá Hjalti Hugason, „Kristnir trúarhættir“, bls. 290.

46 Jarðarfarir og aðrar athafnir á ævihátíðum fóru tíðum fram í tengslum við almennar guðspjónustur.

47 Porri kirkna var lengi í einkaeigu og notaði eigandinn pær á ýmsan hátt. Pá voru pær stundum notaðar í opinberum tilgangi, pað er til pinghalds eða fundarhalda. Eftir að söfnuðir tóku við yfirráðum og eignarhaldi kirkjuhúsanna breyttist petta. Hjalti Hugason, „Kristnir trúarhættir“, bls. 150-158.

48 Раð átti við um meðhjálpara við guðspjónustur en einnig hringjara og forsöngvara. Framan af skyldu sóknarnefndir vera presti til að aðstoðar en báru litla sjálfstæða ábyrgð. Loks höfðu sumir prestar aðstoðarpresta.

49 Hjalti Hugason, „Séra Pétur Sigurgeirsson“, bls. 32-44. Kirkja var reist á Akureyri 1862 og fyrsti prestur á Akureyri fékk veitingu 1881. Áður hafði prestssetur verið á Hrafnagili. Björk Ingimundardóttir, Prestaköll, sóknir og prófastsdemi á Íslandi II, Reykjavík: Pjóðskjalasafn Íslands, 2019, bls. 417, 421-422.

50 Hjalti Hugason, „Séra Pétur Sigurgeirsson“, bls. 10. 
helgar og hátíðir heldur tók einnig að eiga sér stað á virkum dögum. Loks hætti kirkjustarfið að rúmast í guðshúsinu einu og pörf varð fyrir aukið rými sem í upphafi var víða mætt með starfi í skólum, félagsheimilum og öðrum hliðstæðum byggingum en síðar í sérstökum safnaðarheimilum. Pá kallaði kirkjustarfið á framlag fleiri en prestanna einna. Fyrst var pörfinni mætt af sjálfboðaliðum sem oft komu úr kven- og bræðrafélögum sem stofnuð höfðu verið í sóknunum. Pessi mannauður kirkjunnar stóð pó víðast mjög höllum fæti andspænis prestunum sem voru einu launuðu og sérhæfðu starfsmenn kirkjunnar. Siððar var tekið að ráða annað fólk til starfa auk presta og organista sem tekið höfðu við af forsöngvurum í „sveitakirkjunni“. Fyrst komu oftast æskulýðsleiðtogar. Fyrir kom að peir væru kennaramenntaðir eða hefðu aðra uppeldismenntun sem jafnvel gat verið undir kirkjulegum formerkjum og pá fengin erlendis. Síðar komu djáknar til sögunnar sem hlotið höfðu starfsmenntun erlendis en síðar við guðfræðideild (nú guðfræði- og trúarbragðafræðideild) Háskóla Íslands og vígst til embættis síns. ${ }^{51}$ Sú tilhneiging hefur pó verið ríkari hér á landi en víðast annars staðar að ráða helst prestsmenntað fólk til hinna nýju starfa í kirkjunni og að vígja pað síðar til prests. Par með hefur prestakirkja viðhaldist hér hvort sem um markaða stefnu hefur verið að ræða eða ekki. ${ }^{52}$ Hefur petta tafið próun „péttbýliskirkju“ í landinu og valdið einhæfni í starfsháttum. Íslenska pjóðkirkjan er pví fremur gamaldags miðað við fjölmargar sambærilegar kirkjur.

Meðan „sveita-“ og péttbýliskirkjan“ vógu enn salt í landinu eða á áttunda áratugi liðinnar aldar starfaði svokölluð starfsháttanefnd á vegum pjóðkirkjunnar (1974-1977 ) sem lagði fram viðamikla skýrslu og hugmyndir um breytta lagaumgjörð um kirkjuna. ${ }^{53}$ Í störfum sínum tók nefndin mið af próun íslenska samfélagsins „[...] frá landbúnaðarsamfélagi sveitanna

51 Sjá Hjalti Hugason, „Séra Pétur Sigurgeirsson“, bls. 9-74. Í Akureyrarkirkju var rými, „kapella“, í kjallara kirkjunnar sem notað var til safnaðar- og félagsstarfs. Hönnun kirkjunnar var lokið 1938 en hún vígð 1940. Við byggingu Laugarneskirkju í Reykjavík var svo gert ráð fyrir sérstöku rými fyrir safnaðarstarf auk guðspjónusturýmisins. Hönnun var lokið 1941 en kirkjan vígð 1949. Pétur H. Ármannsson, „Akureyrarkirkja. Byggingarsaga kirkjunnar, Lýsing kirkjunnar“, Kirkjur Íslands 10, ritstjórar Jón Torfason og Porsteinn Gunnarsson, Reykjavík: Pjóðminjasafn Íslands og fleiri, 2007, bls. 11-25, hér bls. 15-16, 23. Sami, „Laugarneskirkja. Byggingarsaga kirkjunnar", Kirkjur Islands 19, ritstjórar Jón Torfason og Porsteinn Gunnarsson, Reykjavík: Pjóðminjasafn Íslands og fleiri, 2012, bls. 12-21, hér bls. 14, 18.

52 Steinunn Arnprúður Björnsdóttir, Reforming Pastors. A Study on Reforms and Attempted Reforms in the ELCI with a Focus on the Role of the Pastors, doktorsritgerð í guðfræði við Háskóla Íslands, 2019, bls. 2-3.

53 Álit starfsháttanefndar pjóðkirkjunnar, 1977, bls. 7-12, 132-135. (Fjölrit). 
til iðnaðarsamfélags borga og bæja. “54 Pá vann hún út frá pví meginmarkmiði að pjóðkirkjan fengi meira sjálfstæði í starfi, aukið sjálfræði um „[...] skipulag starfsmanna sinna“ og að „leikmannastarf“ kirkjunnar yrði eflt og „leikmönnum“, pað er óvígðu starfs- og trúnaðarfólki, veitt aukin aðild að ákvarðanatöku í kirkjumálum. ${ }^{55}$ Nefndin var meðvituð um að tillögur hennar lutu fremur að skipulagsmálum en starfsháttum. Pá virðist ljóst að hún hefur tekið mið af peirri hefðbundu skoðun að pjóðkirkjan væri fremur „pjóðfélagsstofnun“ en trúfélag. ${ }^{56}$ Breyttur kirkjuskilningur í pá veru varð enda ekki ofan á í opinberri stefnumörkun fyrr en tuttugu árum síðar (sjá framar). Prátt fyrir áhuga nefndarmanna fyrir að efla starf óvígðra virðast tillögur peirra um stofnunarlega uppbyggingu að mestu rúmast innan ramma hefðbundinnar prestakirkju. Мeð peim tillögum sínum að miða störf einstakra presta við prófastsdæmi en ekki prestaköll, að auka samstarf peirra sem og að greina á milli „frumpjónustu“ kirkjunnar í öllum sóknum landsins og „sérpjónustu“ sem færi eftir pörf og aðstæðum á hverjum stað stefndi nefndin pó að markvissri próun pjóðkirkjunnar yfir í „péttbýliskirkju“ “. ${ }^{77}$ Tillögurnar höfðu takmörkuð áhrif til skamms tíma. Pó má segja að pær hafi um margt lagt hugmyndagrunn að peim breytingum sem fram komu undir lok tuttugustu aldar pótt hægt hafi miðað í átt til breyttra starfshátta og aukins samstarfs.

Hér framar var vikið að ýmsum nýjum hlutverkum sem pjóðkirkjan og prestar hennar hafa gengið inn í samtímis breytingu hennar úr hefðbundinni „sveitakirkju“ í nútímalegri „péttbýliskirkju“. Um svipað leyti og sú breyting gekk yfir hætti pjóðkirkjan að sinna ýmsum gömlum hlutverkum sem hún hafði gegnt um aldaraðir. Flest tengdust pau margháttuðu eftirliti sem hún hafði haft með hendi til dæmis á sviði fræðslumála. Sá reginmunur var á hefðbundnum hlutverkum „sveitakirkjunnar“ og nýjum verkefnum „péttbýliskirkjunnar“ að gömlu hlutverkin voru almennt formleg og rækt á grundvelli laga eða annarra opinberra fyrirmæla væru pau ekki hluti af hefð eða reglum kirkjunnar sjálfrar eins og flest sem að helgihaldi laut. Nýju hlutverkin voru á hinn bóginn sjálftekin og pví óformleg. Eins og drepið var á má pó rekja pau flest til gamalgróinna starfssviða kirkjunnar á vettvangi fræðslu, boðunar og kærleikspjónustu. Einstaklingsbundið frumkvæði presta og síðar samtaka peirra réðu líka oft miklu um á hvern hátt kirkjan

54 Sama rit, bls. 11.

55 Sama rit, bls. 15, 28, 31.

56 Sama rit, bls. 132.

57 Sama rit, bls. 53-58. 
axlaði ný hlutverk og tók upp nýja starfshætti. ${ }^{58}$ Má líta svo á að breytingin hafi ekki verið formgerð fyrr en eftir áratugapróun er pjóðkirkjan tók upp pað kjörorð sem hún starfar nú undir — Biðjandi, boðandi, bjónandi. ${ }^{59}$

Eins og fram er komið var pjóðkirkjan hreinræktuð „sveitakirkja“ fram á síðari hluta tuttugustu aldar er starfshættir hennar tóku í vaxandi mæli að mótast af aðstæðum í nútímasamfélagi. Próunin hefur pó gengið hægt og stafar pað ekki síst af tregðu kirkjunnar til að ráða aðra en presta til starfa jafnvel pótt viðkomandi sé að minnsta kosti í upphafi ætluð störf á öðrum sviðum en helgihaldi. Skýrir petta að nokkru einangrun kirkjunnar í samfélaginu meðan fjölbreyttari starfshættir í blönduðum starfshópum eru líklegir til að auka snertifleti kirkjunnar við umhverfi sitt.

\section{Sambafing og aðgreining prestastéttarinnar}

Hér framar er látið að pví liggja að íslensku pjóðkirkjuna megi skoða sem prestakirkju og að pað hafi jafnvel valdið stöðnun og einangrað hana í samfélaginu. Með prestakirkju er átt við kirkju par sem prestar eru einir að störfum líkt og raun var á um daga „sveitakirkjunnar“. Мeð orðinu er pó líka átt við kirkju par sem prestar hafa augljós völd eða forskot umfram aðra til áhrifa á sviði kirkjumála án pess að embættisguðfræði viðkomandi kirkju ætli peim endilega slíka sérstöðu eins og raun er á um flestar lútherskar kirkjur. ${ }^{60}$ Pær leggja að minnsta kosti í orði kveðnu áherslu á svokallaðan almennan prestdóm en í honum felst að allir skírðir einstaklingar skuli vera virkir og bera ábyrgð í kirkjunni. Vegna pess hve hreinræktuð prestakirkja

58 Pétur Pétursson, „Pjóðkirkja, frelsi og fjölbreytni“, Til móts við nútímann, Kristni á Íslandi IV, ritstjóri Hjalti Hugason, Reykjavík: Alpingi, 2000, bls. 197-421, hér bls. 353-357. Hjalti Hugason, „Séra Pétur Sigurgeirsson“, bls. 38-40.

59 Petta kjörorð endurspeglast skýrt í Sampykktum um innri málefni pjóðkirkjunnar til dæmis par sem segir: „Skipulag pjóðkirkjunnar birtir að hún er líkami Krists og farvegur návistar hans meðal mannanna. Hún er send til að biðja, boða og pjóna.“ „Sampykktir um innri málefni pjóðkirkjunnar, II. Grunneining kirkjunnar [án bls.tals]“ , Kirkjan, sótt 4. febrúar 2021 af https://kirkjan.is/library/Files/Adrarheimildir/Sampykktir\%20um\%20innri\%20málefni\%20kirkjunnar.pdf.

60 Ekki er augljóst að prestar hafi mikil formleg völd umfram aðra í pjóðkirkjunni. Peir eru til dæmis innan við helmingur kjörinna fulltrúa á kirkjupingi. Pegar tekið er tillit til að svo til allir starfsmenn kirkjunnar eru prestar er ljóst að peir hafa yfirburða áhrifastöðu. Pá blasir við að prestar eru oftast áhrifameiri á kirkjupingi en óvígðir fulltrúar sem oft kvarta undan áhrifaleysi á pinginu. Pá benda margir á að biskup sé valdamikill í pjóðkirkjunni. Kann par að valda miklu að mörg verkefni stjórnarráðsins á sviði kirkjumála voru í lok 20. aldar flutt til Biskupsstofu. Auk pess er biskup forseti kirkjuráðs sem fer með víðtækt framkvæmdavald í kirkjunni. 
íslenska pjóðkirkjan er verður gerð sérstök grein fyrir langtímapróun íslensku prestastéttarinnar í pessum kafla og peim sem á eftir fylgja.

Prestar voru teknir til starfa hér áður en kirkjan varð til sem stofnun. Fyrst í stað höfðu peir ólíkan bakgrunn og komu bæði úr efstu og neðri lögum samfélagsins. Meðan svo var er tæpast mögulegt að ræða um presta sem samstæðan pjóðfélagshóp eða stétt. ${ }^{11}$ Pá má ætla að prestsvígsla og prestdómur hafi haft mjög mismunandi merkingu eftir pví hvort áttu í hlut háeða lágstéttarprestar. Prestar af lágum stigum hafa borið uppi helgihaldið og prestspjónustuna í skjóli kirkjueigenda sem oft voru prestvígðir eða annars hástéttarprests sem var lausari við og helgaði sig öðrum hlutverkum í kirkjunni og/eða samfélaginu. Lágstéttarprestar hafa pá verið nokkurs konar staðgenglar (lat. vicarius) hástéttarprestanna. ${ }^{62}$

Prestsævi Guðmundar Arasonar góða (1160-1237) varpar skýru ljósi á petta. Hann var af höfðingjaætt en óskilgetinn og var hann pví „barinn til bókar" og honum fundinn viðunandi staður í kirkjunni. Eftir að hafa pjónað sem pingaprestur á fáeinum stöðum í Skaga- og Eyjafirði var hann kallaður til að verða heimilisprestur eins helsta höfðingja Norðlendinga, Kolbeins Tumasonar (1173-1208) á Víðimýri. Eftir pað virðist hann fljótt hafa orðið einn pekktasti helgisiðafræðingur og sálusorgari landsins og varði miklum hluta ársins fjarri brauði sínu. ${ }^{63}$ Meðan Guðmundur góði rækti prestshlutverk sitt á landvísu hefur ekki verið prestslaust á Vỉðimýri heldur hefur lágstéttarprestur eða jafnvel -prestar annast pjónustu par. Guðmundur hafði að sönnu mikla sérstöðu um sína daga og getur tæpast pjónað sem almennt dæmi um hvernig hástéttarprestar ræktu prestshlutverkið. Algengara hefur líklega verið að peir hafi fremur helgað sig veraldlegum hlutverkum sem fylgdu peim höfðingjadómi sem peir voru bornir til. Guðmundur gerði raunar eina tilraun til að ganga inn í slíkt hlutverk. ${ }^{64}$ Nokkur hvörf hafa

${ }_{61}$ Hjalti Hugason, Frumkristni og upphaf kirkju, bls. 232-243. Sjá og Orri Vésteinsson, The Christianisation of Iceland. Priests, Power and Social Change 1000-1300, London: University College, 1996, bls. 228-291. (Doktorsritgerð).

62 Í slíkum tilvikum hefur verið litið á tekjustofn hástéttarklerksins sem nokkurs konar praebenda (lat.) en pað orð var viðhaft um brauð sem stóðu straum af embætti háklerka, til dæmis við dómkirkjur, án pess að peir sinntu peim sjálfir nema stöku sinnum á ári. Göran Inger, „Prebende“, Kulturbistoriskt lexikon för nordisk medeltid från vikingatid till reformationstid XIII, Malmö: Allhems förlag, 1968, bls. 416-420.

63 Hjalti Hugason, „Áfallatengt álagsheilkenni á miðöldum? Ráðgátan Guðmundur Arason í ljósi meðferðarfræða nútímans“, Skirnir 186: vor/2012, bls. 98-124, hér bls. 112 .

64 „Prestssaga Guðmundar góða“, Sturlunga saga I, Jón Jóhannesson, Magnús Finnbogason og Kristján Eldjárn sáu um útgáfuna, Reykjavík: Sturlunguútgáfan, 1946, 
svo orðið í pessu efni í kjölfar pess að erkibiskup í Niðarósi gaf 1190 út fyrirmæli um að ekki mætti vígja goðorðsmenn og par með sameina prestsembætti og veraldlegt höfðingjahlutverk.$^{65}$ Hefur pað væntanlega dregið úr áhuga manna úr hæsta lagi samfélagsins að taka vígslu nema peir sem eygðu möguleika á biskupsdómi. Eftir pað hefur dregið saman með prestum og peir orðið nær pví að gegna sambærilegum hlutverkum óháð félagslegum bakgrunni.

Torvelt er að kanna félagslega samsetningu prestastéttarinnar fyrr en komið er fram undir 1700. Pó hefur hún ætíð verið ósamstæð hvað félagslegum bakgrunni, efnalegri afkomu, menntun og menningu viðkom. ${ }^{66}$ Eftir að prestsfjölskyldur komu til sögunnar eftir siðaskipti hefur stéttin pó í vaxandi mæli tekið að endurnýjast innan frá og par með orðið samstæðari hvað félagslegan bakgrunn áhrærði. Petta gerðist með pví að prestssynir og/eða dóttur- og sonarsynir presta urðu öðrum fremur prestar. Á fyrrgreindum tíma voru tæpir 2/3 pjónandi sóknarpresta prestssynir og er pá ekki tekið tillit til peirra sem voru á annan hátt af prestaættum. ${ }^{67}$ Félagslegur uppruni peirra sem vígðust til prests á fyrri hluta nítjándu aldar var aftur á móti pannig að um 57 prósent voru prestssynir en prestar voru pá um tvö prósent pjóðarinnar. Um fjórðungur var aftur á móti bændasynir. ${ }^{68}$ Bakgrunnur presta varð svo að nýju fjölskrúðugri eftir að landspróf var komið á (1946) en eftir pað tóku fleiri en börn embættis- og menntamanna að öðlast langskólamenntun.

Um miðja nítjándu öld tók próun samfelldrar prestastéttar kipp í ýmsu tilliti. 1847 var Prestaskólinn stofnaður í Reykjavík. ${ }^{69}$ Eftir pað dró hratt saman með prestum hvað menntun áhrærði. Fyrir daga Prestaskólans mátti

bls. 116-159, hér bls. 130-131.

65 Gunnar F. Guðmundsson, Islenskt samfélag og Rómakirkja, Kristni á Íslandi II, ritstjóri Hjalti Hugason, Reykjavík: Alpingi, 2000, bls. 42.

66 Christina Folke Ax, „Íslensku prestarnir og bréf peirra til landsnefndarinnar 17701771“, Landsnefndin fyrri 1770-1771 II, ritstjórar Hrefna Róbertsdóttir, Jóhanna P. Guðmundsdóttir, Reykjavík: Pjóðskjalasafn Íslands, Ríkisskjalasafn Danmerkur, Sögufélag, 2016, bls. 21-38, hér bls. 23, 29.

67 Hjalti Hugason, „Sóknarprestar á Íslandi um aldamótin 1700. Félagssöguleg forkönnun“, Ritröð Guðfreðistofnunar 28/2009, bls. 82-113, hér bls. 100-103.

68 Hjalti Hugason, Bessastadaskolan. Ett försök till prästskola på Island 1805-1845, Skrifter utgivna av Svenska kyrkohistoriska föreningen II ny följd, Uppsölum: Uppsala universitet, 1983, bls. 24, 100-103. (Doktorsritgerð).

69 Um próun, stöðu og hlutverk prestastéttarinnar frá um 1830 sjá Pétur Pétursson, Church and Social Change. A Studie of the Secularization Process in Iceland 1830-1930, Lundi: Plus Ultra, 1983, bls. 52-79. (Doktorsritgerð). 
finna lærðustu menn landsins í röðum presta en á hverjum tíma höfðu fáeinir peirra dvalið árum saman við erlenda háskóla en pó aðeins Kaupmannahafnarháskóla eftir siðaskipti. Fyrir tilkomu Prestaskólans nægði brottfararpróf úr latínuskóla pó til embættisgengis í íslensku kirkjunni og flestir prestar höfðu ekki hlotið frekari menntun. Prófinu var jafnvel hægt að ljúka utanskóla fram um 1830 eftir einkakennslu sem oft var mögulegt að öðlast í heimahéraði. ${ }^{70}$ Pess voru raunar mörg dæmi að menn sem hlotið höfðu slíka menntun staðnæmdust í bændastétt. ${ }^{71}$ Uppistaðan í tekjum peirra kom einnig af búunum sem peir ráku á prestssetrum eða öðrum ábýlisjörðum sínum. Tekjur presta voru pví misháar. Menntun og menning presta langt fram á nítjándu öld purfti pví ekki að greina pá svo mjög frá bændastéttinni. Efnalega skáru peir prestar sem verr voru settir sig heldur ekki frá bændastéttinni. Hárfín lína greindi pó presta jafnan frá sóknarbörnunum og munaði par mest um hlutverk peirra. ${ }^{72}$ Gilti pað vissulega einkum um tekjuhærri presta sem gátu helgað sig prestshlutverkinu en purftu ekki að ganga að almennum bústörfum að staðaldri. ${ }^{73}$ Öllum prestum bar pó að vera fyrirmynd annarra, leiðbeina fólki í siðferðislegum efnum og áminna pá sem brutu af sér á pví sviði. Einnig var pess vænst að peir gætu veitt leiðsögn um bústjórn og annað sem til framfara horfði. ${ }^{74}$ Olli pað pví að mörgum prestum var sérstaklega umhugað um ýmis framfaramál samfélagsins. ${ }^{75}$ Slæm kjör slæfðu pó

70 Um 1700 höfðu um 57\% pjónandi presta í Skálholtsbiskupsdæmi lokið prófi frá stólsskóla (hæsta menntun) en rúm 65\% í Hólabiskupsdæmi. Um 40 \% höfðu hlotið sambærilega menntun með einkakennslu í Skálholtsbiskupsdæmi en um 34 \% fyrir norðan. 27 prestar höfðu pá numið lengur eða skemur við Kaupmannahafnarháskóla. Á fyrri hluta 19. aldar var landið eitt biskupsdæmi. Af peim sem vígðust á tímabilinu 1805-1846 höfðu um 60\% lokið latínuskólanámi (hæsta menntun), rúm 28\% hlotið einkakennslu og rúm 11\% numið lengur eða skemur við Hafnarháskóla. Hjalti Hugason, Bessastadaskolan, bls. 87, 94-100. Hjalti Hugason, „Sóknarprestar á Íslandi um aldamótin 1700“, bls. 103-107. Christina Folke Ax, „Íslensku prestarnir", bls. 24, 25, 37.

71 Peir sem ekki tóku vígslu strax að menntun lokinni en vildu halda embættisgengi urðu að halda pví við með að leysa af hendi skrifleg verkefni sem peim voru send á latínu. Á árunum 1805-1846 tóku á bilinu 42-71 pátt í slíku prófi. 1824 var priðjungur peirra í bændastétt. Hjalti Hugason, Bessastadaskolan, bls. 88-89. Sjá Hrafnkell Lárusson, Lýðreði i mótun, bls. 46.

72 Christina Folke Ax, „Íslensku prestarnir“, bls. 30, 37. Arnljótur Ólafsson, „Um prestamálið“, Norðlingur, 16. maí 1878, bls. 217-219.

73 Christina Folke Ax, „Íslensku prestarnir, bls. 32-33.

74 Sama rit, bls. 21, 37. Sjá Hrafnkell Lárusson, Lýdreðð i mótun, bls. 46.

75 Christina Folke Ax, „Íslensku prestarnir“, bls. 31. 
áhrifamátt margra presta í pessu efni. ${ }^{76} 1907$ var launakerfi presta loks breytt en pá voru peir settir á fast tiltekin árslaun úr prestlaunasjóði og síðar ríkissjóði. ${ }^{77}$ Áfram voru tekjur presta pó mismunandi eftir pví hvort peir gegndu rýrum eða „feitum“ prestaköllum og réðst munurinn að mestu af gæðum prestsseturs sem fylgdi flestum brauðum. Á tuttugustu öld varð stéttin loks samstæður hópur háskólamenntaðra embættismanna í pjónustu hins opinbera. Prestar urðu par með í vaxandi mæli hvítflibbamenn. Um leið varð stéttin sérhæfðari hvað hlutverk áhrærði og hefur hvort tveggja gert línuna sem greindi prestastéttina frá öðrum greinilegri.

\section{Breytileg blutverk klerka og kirkju}

Vegna fábreyttra innviða í íslenska samfélaginu á trúarbragðaskiptatímanum tók kirkjan snemma að gegna ýmsum samfélagshlutverkum sem lágu fjarri trúarlega sviðinu. Breytir pá litlu hvort gengið er út frá nútímaskilgreiningu eða peim skilningi sem ætla má að hafi gilt um mörk veraldlegra og trúarlegra mála pegar pau voru önnur og ógleggri. Kirkjan gegndi til að mynda mikilvægu hlutverki í stjórnskipan landsins. Biskupar áttu sæti á miðpalli í lögréttu ásamt lögsögumanni og 12 goðum úr hverjum fjórðungi en peir skyldu ráða „lögum og lofum“ á pinginu. ${ }^{78}$ Í lögréttu voru, eins og nafnið bendir til, lög rétt og nýmæli gerð. Að nútímaskilningi fór hún pví með löggjafarvald í samfélaginu og var par með meginstoð stjórnskipanarinnar. ${ }^{79}$ Gátu atkvæði biskupa jafnvel ráðið úrslitum ef ágreiningur varð um val lögsögumanns. ${ }^{80}$ Pá áttu biskupar og par með kirkjan að koma að nokkrum veraldlegum málum sem leysa mátti með gerðardómi biskups utan pings. Var par einkum um að ræða framfærslu fólks sem ekki gat séð sér farborða á eigin spýtur. ${ }^{81}$ Par var sem sé um velferðarmál að ræða að nútímaskilningi. Eru pá ónefndir málaflokkar sem beinlínis heyrðu undir kirkjuna eins og til að mynda hjúskaparmál.

Kirkjan gegndi líka mikilvægu hlutverki á sviðum par sem stöðlun og samræming var mikilvæg. ${ }^{82}$ Meðan lög voru varðveitt á handrituðum laga-

76 Sama rit, bls. 21, 26, 29.

77 Tekjumunur hélst pó vegna sóknartekna (gjalda frá sóknarbörnum) og tekna er prestar höfðu af prestssetrum og ef til vill öðrum kirkjujörðum.

78 Grágás, bls. 464.

79 „Inngangur [Grágás]“, bls. xxi.

80 Grágás, bls. 459.

81 Sama rit, bls. 105, 186.

82 Hjalti Hugason, Frumkristni og upphaf kirkju, bls. 359-367. 
skrám gætti til dæmis oft ósamræmis sem ýtti undir réttaróvissu. Pessum vanda var mætt í Lögréttupætti Grágásar á eftirfarandi hátt:

[...] pað skulu lög vera á landi hér sem á skrám standa. En ef skrár skilur á, og skal pað hafa er stendur á skrám peim er biskupar eigu. Nú skilur enn peirra skrár á, pá skal sú hafa sitt mál er lengra segir peim orðum er máli skipta með mönnum. En ef pær segja jafnlangt, og bó sitt hvort, pá skal sú hafa sitt mál er í Skálaholti er. ${ }^{83}$

Er kirkja var komin á traustan grunn í landinu hafði hún einnig á að skipa ýmiss konar kirkjulegum stofnunum sem hver um sig annaðist ýmis samfélagshlutverk auk pess kirkjulega tilgangs sem peim var ætlað að pjóna. Er hér átt við biskupsstólana, klaustrin, prestssetrin og sóknarkirkjurnar auk kristbúa og skyldra stofnana. Við biskupsstólana og klaustrin fór fram kennsla og menntastarf sem einnig gat farið fram á prestssetrum. Á biskupsstólunum, í klaustrunum og á kristbúunum var stundað líknarstarf sem nú á dögum mætti nefna velferðarpjónustu. Auk pess var svo ástunduð umönnun og jafnvel lækningar í klaustrunum. ${ }^{84}$ Kirkjan kom pannig að málaflokkum sem nú til dags væru kölluð mennta-, félags-, velferðar- og heilbrigðismál auk trúmálanna. Misjafnt var hve veigamikil hlutverk kirkjunnar voru á hverju pessara sviða og hve lengi hún gegndi peim. Lengst voru menntaog kirkjumálin samofin eða allt fram á tuttugustu öld. Hinir málaflokkarnir greindust fyrr frá kirkjumálunum.

Fyrstu formlegu kröfurnar sem gerðar voru um afstæða eða bóklega kunnáttu hér á landi og par með fyrsta vísi að námskrá má finna pegar í Kristinna laga pætti Grágásar par sem krafist var að fólk kynni Faðir vorið, Postullegu trúarjátninguna sem og pað sem hafa purfti yfir pegar börn voru

83 Grágás, bls. 463. Hér skiptir máli hvers eðlis Grágás var, bað er hvort hún var lögbók í nútímaskilningi eða sundurleitara safna réttarheimilda. Nú mun almennt vera litið svo á að hún hafi orðið til án atbeina „löggjafarvalds“ og ekki hlotið löggildingu heldur verið eitt af mörgum lagasöfnum sem til voru og gátu verið misýtarleg. Pá purfa öll ákvæði hennar ekki að hafa verið í gildi á sama tíma. „Inngangur [Grágás]“, bls. xxiii-xxiv. Sjá Grágás, bls. 463. Petta dregur ekki úr mikilvægi hennar sem réttarheimildar.

84 Sjá Steinunn Kristjánsdóttir, Sagan af klaustrinu á Skriðu, Reykjavík: Sögufélag, 2012, bls. 195-247, 327-333. Steinunn Kristjánsdóttir, Leitin að klaustrunum. Klausturbald á Íslandi i fimm aldir, Reykjavík: Sögufélag, Pjóðminjasafn Íslands, 2017, bls. 46, 48, 478. Loftur Guttormsson og Helgi Skúli Kjartansson, „Siðaskipti og fátækraframfærsla. Athugagreinar í tilefni af nýlegum útleggingum“, Saga LII: 1/2014, bls. 119-143. 
skírð skemmri skírn í neyðartilvikum. ${ }^{85}$ Var petta uppistaða í formlegri alpýðufræðslu út miðaldir pótt smám saman hafi verið aukið við petta lágmark. Eftir siðaskipti tók svokölluð kverfræðsla við sem fyrst í stað byggði á Freðum Lúthers hinum minni (1529) en auk fyrrgreinds efnis var par að finna boðorðin tíu, auk texta sem lutu að skriftum og kvöldmáltíð. ${ }^{86}$ Fræðslan var veitt á heimilum undir eftirliti presta sem fór fram við fyrstu altarisgöngu í kapólskum sið en húsvitjanir og fermingu í lútherskum.

Utan um pessa skírnarfræðslu kirkjunnar byggðist svo frekari menntun albýðu og kom par lestrarkennsla fyrst til sögunnar. Um miðja átjándu öld var komið hér á fastmótuðu kerfi kirkjulegrar heimafræðslu par sem yfirvöld settu viðmiðanir, prestar önnuðust eftirlit en foreldrar eða húsbændur voru ábyrgir fyrir framkvæmdinni. Áskilin var kunnátta í kristnum fræðum og lestri sem átti ekki síst að pjóna trúfræðslunni. ${ }^{87}$ Örla tók á veraldarvæðingu albýðufræðslunnar er tekið var að krefjast kunnáttu í skrift og reikningi með fræðslulögum $1880{ }^{88}$ Pá tók barnafræðslan að verða heimilunum ofviða og stofnun heimangönguskóla í péttbýli og farskóla í dreifbýli fór í vöxt. Мeð nýjum fræðslulögum 1907 og stofnun Kennaraskóla Íslands ári síðar urðu fræðslumálin sjálfstæður málaflokkur aðgreindur frá kirkjumálunum og skólakerfi tók að próast aðskilið frá kirkjunni. ${ }^{89}$ Á pessum tíma gengu ýmsir guðfræðingar og jafnvel prestar til liðs við skólakerfið. Góður fulltrúi peirra var Magnús Helgason (1857-1940) fyrsti skólastjóri Kennaraskólans en hann hafði bæði verið pjónandi prestur og kennari við Flensborgarskóla..$^{90}$ Óvíst er að hann og aðrir af hans kynslóð sem líkt var ástatt með hafi litið svo á að peir hafi snúið baki við kirkjunni og hafið veraldleg störf. Allt eins er líklegt að peir hafi aðeins talið sig breyta um áherslur í samfelldu fræðslustarfi sem mögulegt var að rækja hvort sem var á vettvangi

${ }_{85}$ Hjalti Hugason, Frumkristni og upphaf kirkju, bls. 367-368.

86 Hjalti Hugason, „Kristnir trúarhættir“, bls. 284-289.

87 Loftur Guttormsson, „Hefðir og nýbreytni 1880-1907“, Skólahald i be og sveit 1880-1945, Almenningsfræðsla á Íslandi 1880-2007 I, ritstjóri Loftur Guttormsson, Reykjavík: Kennaraháskóli Íslands, Háskólaútgáfan, 2008, bls. 21-71, hér bls. 21-31.

88 Stjórnartiððindi 1880 A, bls. 6-9 (1. nr. 2/1880). Loftur Guttormsson, „Hefðir og nýbreytni“, bls. 31-35. Sjá Hrafnkell Lárusson, Lýdreði í mótun, bls. 51-56.

89 Stjórnartíðindi 1907, bls. 380-397 (1. nr. 59/1907). Loftur Guttormsson, „Sundurleit skólaskipan 1907-1945“, Skólahald i be og sveit 1880-1945, Almenningsfræðsla á Íslandi 1880-2007 I, ritstjóri Loftur Guttormsson, Reykjavík: Kennaraháskóli Íslands, Háskólaútgáfan, 2008, bls. 75-159, hér bls. 75-89.

90 Björn Magnússon, Guðfreðingatal 1847-1976, Reykjavík: Leiftur, 1976, bls. 286287. 
kirkju eða skóla. Með nýjum fræðslulögum 1926 var svo gerð skýrari aðgreining milli kirkju og skóla par sem kristinfræðikennsla í skólum miðaðist ekki lengur við fermingarfræðslu kirkjunnar með pví að greint var á milli biblíusögukennslu er kennarar skyldu annast og kver- eða trúfræðikennslu sem áfram skyldi vera í höndum presta. ${ }^{91}$ Eftir petta verður ekki litið svo á að kirkjan eða prestar hafi gegnt formlegum hlutverkum á sviði fræðslumála pótt margir prestar sætu í skólanefndum, væru prófdómarar eða stunduðu jafnvel kennslu meðfram prestspjónustu. ${ }^{92}$ Pess ber pó að geta að meðan unglingaskólar voru fáir bjuggu fjölmargir prestar fleiri eða færri pilta undir nám í latínuskóla og brúuðu pannig bilið milli albýðufræðslu og langskólanáms. Vegna fermingarfræðslunnar auk eftirlits síns með heimafræðslunni höfðu prestar enda öðrum fremur yfirlit yfir námshæfileika ungmenna í sóknum sínum. Fjölmargir prestar hafa líka verið helstu hvatamenn pess að drengjum væri komið til mennta. ${ }^{93}$

Bókleg framhaldsmenntun var alfarið á forræði kirkjunnar frá upphafi og að minnsta kosti fram undir aldamótin 1800. Helsta hlutverk hennar var enda að mennta presta. Allt frá pví biskupsstólar komust á hefur væntanlega farið fram prestsmenntun í Skálholti og á Hólum en líklega með einhverjum hléum. Óljóst er pó hvenær skólar í nútímamerkingu hafa komist par á og hve stöðugt starf peirra var. Við klaustrin hefur ugglaust verið stunduð ápekk kennsla fyrir verðandi klausturfólk (innri skóli) og jafnvel aðra (ytri skóli).94 Hliðstæða menntun var svo jafnframt hægt að öðlast með einkakennslu sem margir prestar stóðu fyrir (sjá framar). Með sameiningu stólsskólanna í Hólavallarskóla í Reykjavík og síðar Bessastaðaskóla hófst veraldarvæðing æðri menntunar í landinu sem hélt svo áfram með stofnun Lærða skólans í Reykjavík 1846. Árið eftir tók Prestaskólinn svo til starfa. Eftir pað verður tæpast litið svo á að Lærði skólinn hafi verið kirkjuleg stofnun. Pví máli

91 Stjórnartíðindi 1926 A, bls. 291-300 (1. nr. 94/1926). Loftur Guttormsson, „Sundurleit skólaskipan“, bls. 110-111.

92 Vert er pó að geta pess að ýmsir prestar í dreifbýli önnuðust unglingakennslu upp á eigin spýtur gegn kennslugjaldi. Einn sá síðasti hefur líklega verið Sigurður Guðmundsson (1920-2010) sem rak unglingaskóla á Grenjaðarstað í Pingeyjarsýslu flest ár 1944-1966. Björn Magnússon, Guðfreðingatal 1847-1976, bls. 359-360. Loftur Guttormsson, „Sundurleit skólaskipan“, bls. 148. Um hlutverk presta á sviði almenningsfræðslu sjá og Pétur Pétursson, Church and Social Change, bls. 59-63.

93 Sjá til dæmis Jens V. Hjaltalín, „Sjálfsævisagan“, „Kátlegur guðsmaður“. Sjálfsavisaga séra fens V. Hjaltalin, [án útgst.]: Flateyjarútgáfan, 2008, bls. 31-143, hér bls. 33.

94 Oft er litið svo á að skólahald hafi hafist snemma og verið stöðugt á biskupsstólunum. Um pað er ekki nægileg vitneskja. Orðið skóli er í fornum ritum oft notað um kennslu en merkir nú kennslustofnun. Kann pað að auka á óvissuna. 
gegndi fremur um Prestaskólann. Frá 1911 hefur Háskóli Íslands annast menntun presta og síðar einnig djákna lengst af án formlegrar aðkomu kirkjunnar bótt um embættis- og/eða starfsmenntun sé að ræða. ${ }^{95}$ Háskólinn var frá upphafi veraldleg stofnun.

Félags- og velferðarmál í sveitasamfélaginu gamla fólust einkum í fátækraframfærslu og síðar einnig barnavernd. Pegar í upphafi byggðar í landinu var tekið að huga að fátækra- eða framfærslumálum og voru pau lengst af að langmestu leyti á forræði hreppa og voru pví veraldlegur málaflokkur. ${ }^{96}$ Við hlið hins samfélagslega kerfis lagði kirkjan pó sitthvað af mörkum á pessu sviði og pá ekki síst á kapólskum tíma.

Samkvæmt fátækrareglugerð sem sett var 1834 áttu prestar að vera hreppstjórum til ráðuneytis í fátækramálum og hafa eftirlit með störfum peirra. Auk pess áttu peir að kalla alla til ábyrgðar: vel stæða til að ala önn fyrir fátækum skyldmennum en pá sem með fyrirhyggjuleysi voru taldir hafa komið sjálfum sér í örbirgð til að bæta ráð sitt og verða sjálfbjarga. ${ }^{97}$ Pá áttu prestar og að líta eftir að aðbúnaður niðursetninga væri sómasamlegur og pá ekki síst uppfræðsla barna. ${ }^{98}$ Samkvæmt reglugerðinni skyldu fátækir settir niður „[...] hjá réttsinnuðum húsbændum [...] á sparsamasta hátt [...]“ og hljóta par „[...] alla nauðpurft [...]“.99 Bændur áttu aftur á móti að njóta hagnaðar af peirri vinnu sem ómagar gátu unnið auk „, [... s sannsýnilegs endurgjalds.“100 Munaðarlaus börn skyldi setja niður hjá húsbændum sem vænta mátti að önnuðust pau „[...] með skynsamlegri umhyggju fyrir peirra velferð, hvartil pað heyrir, að pau njóti tilhlýðilegrar uppfræðíngar,

95 Í seinni tíð hefur pjóðkirkjan kostað hluta af stöðugildi lektors í kennimannlegum fræðum á grundvelli samstarfssamnings við Guðfræði- og trúarbragðafræðideild Háskóla Íslands. Hún hefur pó ekki haft aðkomu að skipan námsins. Pá krefst pjóðkirkjan nú starfspjálfunar af verðandi prestum og djáknum og annast pann pátt menntunarinnar sjálf án pátttöku GTD.

96 Jónas Guðmundsson, „Fátækraframfærslan á Íslandi“, Félagsmál á Íslandi, ritstjóri Jón Blöndal, Reykjavík: Félagsmálaráđuneytið, 1942, bls. 149-182, hér bls. 149153. Pórður Eyjólfsson, Alpingi og héraðsstjórn, bls. 5-13. Lýður Björnsson, Saga sveitarstjórnar á Ílandi I, Reykjavík: Almenna bókafélagið, 1972, bls. 65-66.

${ }_{97}$ Lovsamling for Islands 10, bls. 425 (reglem. 8. janúar 1834). Sverrir Kristjánsson, „Tímabilið 1845-1900“, Alpingi og Félagsmálin, Reykjavík: Alpingissögunefnd, 1954, bls. 9-37, hér bls. 10.

98 Lovsamling for Island 10, bls. 424, 425, 428 (reglem. 8. janúar 1834). Lýður Björnsson, Saga sveitarstjórnar I, bls. 175.

99 Lovsamling for Island 10, bls. 428 (reglem. 8. janúar 1834).

${ }^{100}$ Sama rit, sama stað. 
og að peim snemma haldist til guðhræðslu, siðlætis og vinnusemi." ${ }^{101}$ Áttu prestar að hafa sérstakt eftirlit með aðbúnaði peirra. Áður en tilskipun um hreppsnefndir tók gildi 1872 komu prestar bó einnig að framkvæmd pessara mála að minnsta kosti par sem hreppstjórar gátu ekki annast pau einir. Samkvæmt tilskipuninni tóku aftur á móti kjörnar hreppsnefndir við fátækramálunum. Prestar önnuðust pó áfram eftirlit með „uppfóstri og uppeldi“ barna og skyldu nefndirnar fara eftir áliti prestsins um málefni beirra. ${ }^{102}$ Reglugerðin frá 1834 um petta viðkvæma mál var eins og að ofan greinir orðuð á mannúðlegan hátt. Í skjóli hennar var framkvæmdin pó sú að hagsmunir framfærslusveitar vógu oftast pyngra en velferð peirra sem á hjálp purftu að halda og var bágstöddum almennt komið fyrir par sem lægsts endurgjalds var krafist. Stóð svo uns fátækralög frá 1905 öðluðust gildi (1907) en samkvæmt peim skyldi haga sveitarstyrk pannig að bæði væri gætt hagsmuna fátækrafélagsins (hreppsins) og parfa og velferðar einstaklinganna (45. gr.). Pví mátti ekki halda „[...] undirboð á framfærslu purfalings“ (46. gr.). ${ }^{103}$

Barnavernd í nútímamerkingu hefur líkt og fátækramálin frá upphafi verið veraldlegt málefni pótt prestar væru lengi kosnir í barnaverndarnefndir í einstökum sveitarfélögum. Par var pó ekki um embættisskyldu að ræða. Рjóðkirkjan hefur og löngum talist meðal félaga og stofnana sem stuðlað hafa að velferð barna. Prestafélagi Íslands var til dæmis ætlað að tilnefna einn af premur fulltrúum í barnaverndarráð samkvæmt fyrstu barnaverndarlögunum (1932). Kennarafélag Íslands skyldi tilnefna annan fulltrúa 1́ ráðið. ${ }^{104}$ Kirkjan og skólinn voru enda pær stofnanir samfélagsins sem næst stóðu málefnum barna.

Ýmsir prestar beittu sér fyrir velferð barna utan opinbera kerfisins og gættu pá oft mannúðlegri sjónarmiða en par réðu ferðinni. Tryggvi Hjörleifsson Kvaran (1892-1940) sem pjónaði Mælifelli í Skagafirði frá 1919 er athyglisvert dæmi um pað. Fljótlega eftir að hann tók við embætti tóku hann og kona hans, Anna Grímsdóttir Thorarensen (1890-1944), að sér dreng á fyrsta ári. Í framhaldinu gekkst presturinn fyrir pví að fimm systkini

${ }^{101}$ Sama rit, sama stað.

102 Tỉindi um stjórnarmálefni Íslands III, 1875, bls. 394-432 (tilsk. 4. maí 1872). Lýður Björnsson, Saga sveitarstjórnar I, bls. 175, 252. Einstakir prestar komu lengi eftir petta að sveitarstjórnarmálefnum en pá sem kjörnir fulltrúar eða annars konar trúnaðarmenn en ekki vegna embættisskyldu. Sjá Pétur Pétursson, Church and Social Change, bls. 64-65, 69.

103 Stjórnartíðindi 1905 A, bls. 280 (1. nr. 44/105).

${ }^{104}$ Símon Jóh. Ágústsson, „Barnavernd“, Félagsmál á Íslandi, Reykjavík: Félagsmálaráðuneytið, 1942, bls. 183-198, hér bls. 183-185, 197-198. 
hans voru tekin í fóstur á „betri heimili“ sveitarinnar með peim kjörum að farið væri með pau eins og pau væru börn fósturforeldranna. Blóðforeldrar barnanna sem voru bláfátæk komust eftir petta vel af með sex börn en hefðu ella purft að segja sig til sveitar. Nokkrum árum síðar dó bóndi frá ellefu börnum sem ekki beið annað hlutskipti en að vera ráðstafað af hreppsnefnd pannig að sem minnstur kostnaður hlytist af. Við jarðarförina hét Tryggvi á „bestu menn“ sveitarinnar að taka börnin án meðgjafar og reynast peim sem eigin börnum. Gekk petta eftir og sjálf tóku Mælifellshjónin pá að sér ellefu ára gamla stúlku. ${ }^{105}$ Ástæður prestsins fyrir pessari athafnasemi virðast hafa verið pær að hann taldi ekki „eftirbreytnivert“ að ala börn upp á sveit meðan pví fylgdi jafn mikil skömm og raun bar vitni á pessum tíma. Pá leit hann svo á að hjálpsemi af pessu tagi væri eðlilegur ávöxtur kristindómsins. ${ }^{106}$ Einnig var sýnilega um að ræða áhrif frá móður Tryggva, Björgu Einarsdóttur (1851-1946). Hún ól upp átta fósturbörn að meira eða minna leyti. Pegar hún gekk í hjónaband með Hjörleifi Einarssyni (1831-1910) presti á Undirfelli í Vatnsdal, sér mun eldri ekkjumanni, gerði hún meðal annars að skilyrði að hún mætti taka börn í fóstur eftir pví sem hugur hennar stæði til. Hafði hún pá pegar tekið að sér bróðurson sinn. ${ }^{107}$ Algengt hefur verið að prestar tækju að sér börn um lengri eða skemmri tíma og jafnvel alið pau upp pótt peir byggju við kröpp kjör. ${ }^{108}$

Fyrsta vísi að stofnunarvæddum lækningum hér á landi er ugglaust að rekja til kirkjulegra stofnana og pá einkum klaustranna. Eftir að örla tók á próun heilbrigðismála sem veraldlegs málefnis með skipun fyrsta landlæknisins (1760) var formlegri aðkomu kirkju og presta að heilbrigðismálum lokið. Meðan læknaskortur var enn í landinu kom fyrir að prestar sem sérstaklega höfðu lagt sig eftir læknisfræði hlytu lækningaleyfi. Um miðja nítjándu öld höfðu að minnsta kosti tveir prestar á Austurlandi slík leyfi. ${ }^{109}$ Pá purfti og

${ }^{105}$ Drengurinn sem tekinn var í fóstur var Kristmundur Bjarnason (1919-2019) rithöfundur og fræðimaður á Sjávarborg. Til dæmis um jafnræðið sem hann bjó við er að pegar fóstra hans lést fékk hann sama arfshlut og dætur hjónanna en var pó ekki ættleiddur. Kristmundur Bjarnason, Í barnsminni. Minningaslitur frá bernskuárum, Sauðárkróki: Sögufélag Skagfirðinga, 2019, bls. 21-23, 220.

${ }^{106}$ Sama rit, bls. 20-21.

${ }^{107}$ Sama rit, bls. 21, 35-36.

${ }_{108}$ Oscar Clausen, Við yl minninganna, Reykjavík: Bókfellsútgáfan, 1960, bls. 192, 218219. Jósef Jónsson, „Minningarorð um séra Jens eftir Jósef Jónsson á Setbergi“, „Kátlegur guðsmaður“. Sjálfsevisaga séra fens V. Hjaltalín, [án útgst.]: Flateyjarútgáfan, 2008, bls. 169-170, hér bls. 170.

${ }^{109}$ Sigurjón Jónsson, Alpingi og heilbrigðismálin, Reykjavík: Alpingissögunefnd, 1950, 
að nýta kunnáttu smáskammtalækna og peirra sem lagt höfou sig eftir albýðlegum lækningum. Við leyfisveitingar peim til handa skyldi leitað meðmæla sóknarprests og hreppstjóra. ${ }^{110}$ Auk pess stunduðu ýmsir prestar slíkar lækningar sjálfir. Prestum voru svo falin einstök verkefni á sviði heilbrigðismála. Lengst af nítjándu aldar áttu peir til að mynda að bólusetja gegn bólusótt en bólusetning var gerð að skilyrði fyrir fermingu í lok aldarinnar. ${ }^{11}$ Framan af tuttugustu öld urðu prestar sérstaklega til sveita auk pess að skrá banamein fólks án pess að læknismenntaður maður hefði gefið út dánarvottorð sem fyrst var tekið að krefjast í kaupstöðum og kauptúnum. ${ }^{12}$ Hefur pað útheimt nokkurrar pekkingar og dómgreindar í sjúkdómsgreiningum.

Allan tímann sem fáum samfélagsstofnunum var til að dreifa og menntun manna var fábreytt, einkum latínuskóla- eða prestsmenntun, gegndu kirkjan og prestastéttin flestum peim hlutverkum sem nú dreifast á margar stofnanir eða heilu samfélagskerfin svo sem á sviði félags- og velferðarmála, heilbrigðis- en einkum pó menntamála eins og sýnt hefur verið. Á fyrstu áratugum tuttugustu aldar var peim hlutverkum sem prestar og par með eiginkonur peirra og heimili gegndu pó tekið að fækka. ${ }^{113}$ Pær breytingar tóku samt langan tíma. Matthías Eggertsson (1865-1955), bróður- og fóstursonur Matthíasar Jochumssonar pjóðskálds, pjónaði Miðgarðaprestakalli í Grímsey 1895-1937. Við lát hans var hlutverkum hans svo lýst:

Ég efast um, að nokkru sinni hafi prestur á Íslandi haft fleiri og margbreytilegri störf en séra Matthías, sem auk höfuðstarfsins sem prestur var einnig forvígismaður eyjarskeggja í veraldlegum málum, sem oddviti og sýslunefndarmaður, auk pess kennari byggðarlagsins, loftskeytastjóri, bókavörður o. fl. Hann stofnaði barnaskóla par, búnaðarfélagið og bindindisfélög, [...]. Hann var á sama hátt forystumaður í búnaðarháttum á eyjunni. Hann hafði venjulega 8-9 störf smá og stór auk prestsstarfsins og flest peirra áratugum samfleytt, eins og t.d. veðurathuganir bæði fyrir vísindastofnun í Kaupmannahöfn og svo fyrir veðurstofuna í Reykjavík. Í

bls. 4. Oscar Clausen, Sögn og saga. Fróðlegir pettir um ævikjör og aldarfar II, Reykjavík: Skuggsjá, 1973, bls. 7-53, hér bls. 19-20, 28-29. Pétur Pétursson, Church and Social Change, bls. 69-70. Hrafnkell Lárusson, Lýdreði í mótun, bls. 46.

${ }^{110}$ Sigurjón Jónsson, Alpingi og heilbrigðismálin, bls. 27.

111 Sama rit, bls. 65.

112 Sama rit, sama stað.

113 Síðhöttur, „Ferðasögur 12. Vestur til Dala“, Morgunblaðið, 24. september 1916, bls. 3-6, hér bls. 4 . 
öllu pessu var hann studdur af mikilhæfri konu sinni, sem stundaði ljósmóðurstörf og hjálpaði sjúkum. ${ }^{114}$

Petta er ekki dæmigerð verklýsing presta pegar komið var fram undir seinna stríð. Í prestakalli sem var jafn sérstaklega sett og Miðgarðaprestakall hafa fleiri verkefni fallið til en víða annars staðar. Veðurathuganir voru ekki gerðar á hverju prestssetri né hefur par heldur verið loftskeytastöð pótt sums staðar hafi aftur á móti verið símstöð sem prestshjónin önnuðust. Flest hinna hlutverkanna geta hafa fallið mörgum prestum í skaut í meira eða minna mæli. Um aldmótin 1900 var til dæmis nánast regla að prestssetrin væru bréfhirðingastaðir sóknanna. ${ }^{15}$ Pá voru mörg dæmi um að prestssetur væru formlegir eða óformlegir samkomustaðir par sem margs konar félagsstarf fór fram meðal annars í tengslum við guðspjónustur. ${ }^{116}$

Í nýsampykktum lögum um pjóðkirkjuna er kveðið á um hlutverk hennar sem ekki er gert í eldri lögum. Um pað segir að pjóðkirkjunni beri að halda úti vígðri pjónustu á landinu öllu og tryggja að allir landsmenn geti átt kost á henni. Pá haldi hún úti ýmiss konar fræðslu og kærleikspjónustu eftir pví sem við verður komið. Auk pess segir að stjórnvöld geti „,...] leitað til pjóðkirkjunnar í störfum sínum telji pau pess pörf.“117 Î pví felst að ríkisvaldið getur falið pjóðkirkjunni hlutverk sem ekki er kveðið á um í lögunum til dæmis pegar almannavarnaástand skapast, hópslys verða eða pörf kemur upp fyrir áfallahjálp. ${ }^{118}$ Af upptalningunni sést að löggjafinn markar pjóðkirkjunni stað á hinu trúarlega sviði hvað hlutverk áhrærir sem og á sviðum par sem pað skarast við velferð og almannaheill án pess að hún beri par neinar lögbundnar skyldur. Petta kemur heim og saman við skilgreiningu pjóðkirkjunnar sem trúfélags.

Hér hefur verið leitast við að gera grein fyrir hvernig formlegum hlut-

${ }^{114}$ Jón Thorarensen, „Séra Matthías Eggertsson“, Kirkjuritið 21: 10/1955, bls. 458460, hér bls. 459.

${ }^{115}$ Hrafnkell Lárusson, Lýðreði i mótun, bls. 58.

${ }^{116}$ Hjalti Hugason, „Kristnir trúarhættir“, bls. 251-256. Sjá Gunnar Benediktsson, Stiklað á stóru. Frá bernsku til brauðleysis, Reykjavík: Bókaútgáfan Örn og Örlygur, 1974, bls. 130-138. Í endurminningum sínum varpar Kristmundur Bjarnason áhugaverðu ljósi á hið flókna félagskerfi sem prestssetur rúmuðu á uppvaxtarárum hans fram undir 1940. Kristmundur Bjarnason, Í barnsminni.

117 „Lög um pjóðkirkjuna“, Alpingi, sótt 28 júní 2021 af https://www.althingi.is/altext/ 151/s/1806.html.

118 „Frumvarp til laga um pjóðkirkjuna. Um einstakar greinar frumvarpsins [um 3. gr.]“, Alpingi, sótt 15. mars 2021 af https://www.althingi.is/altext/151/s/0996.html. 
verkum kirkju og presta hennar fækkaði í aldanna rás er nýjar samfélagsstofnanir leystu hana af hólmi eftir pví sem innviðir samfélagsins urðu fjölpættari. Jafnframt hefur kirkjan sérhæfst og er hún nú fyrst og fremst trúarstofnun — og í vaxandi mæli trúfélag. Ljóst er að pessi próun hefur í grundvallaratriðum breytt ásýnd kirkjunnar og hlýtur að valda miklu um afstöðu fólks er pað er spurt um samleið pess með pjóðkirkjunni eða hvort pað kjósi að tilheyra henni áfram. Hér er pví fundin ein helsta skýringin á pví hvers vegna líta má svo á að staða kirkjunnar sé nú á hverfanda hveli.

\section{Lokaorð}

Í greininni var sýnt fram á að frá pví upp úr trúarbragðaskiptum og raunar allt fram á nítjándu og tuttugustu öld hafi kirkjan verið burðarstoð í innviðum íslenska samfélagsins. Sinnti hún pá mikilvægum hlutverkum sem síðar færðust yfir til ýmissa annarra samfélagsstofnana og teljast nú sjálfstæðir málaflokkar órafjarlægir hinu trúarlega sviði. Má par nefna mennta-, félags-, velferðar- og jafnvel heilbrigðismál. Petta gerðist um leið og samfélagið próaðist úr einföldu sveitasamfélagi yfir í fjölgreint péttbýlissamfélag. Рað samfélagshlutverk kirkjunnar sem hvað pyngst vóg var pó að standa vörð um hugmyndafræðilega og menningarlega einingu samfélagsins á trúarlegum grundvelli. Pví hlutverki gegndi hún allt par til einstaklingfrelsi og lýðræðisvæðing hófst á síðasta fjórðungi nítjándu aldar í kjölfar pess að pjóðin fékk stjórnarskrá um sérmál sín. Í stað einingarviðleitninnar hefur hugsjón frelsis og fjölmenningar nú rutt sér til rúms. Trúarmenning fyrri tíma hefur og vikið fyrir sívaxandi einstaklingshyggju. Í kjölfarið varð kirkjan sérhæfðari og er nú aðeins ætluð formleg hlutverk á hinu trúarlega sviði en líta má á pað sem jaðarsvæði í nútímasamfélagi. Afleiðingar pessarar próunar er meðal annars að ekki er lengur sjálfsagt að hvert og eitt okkar finni til djúprar samsömunar við pjóðkirkjuna eða velji að tilheyra henni frá vöggu til grafar. Er parna að leita helstu skýringanna á peirri nýju stöðu sem pjóðkirkjan hefur hafnað í og hér er lýst svo að hún sé á hverfanda hveli. Hér er aftur á móti litið svo á að ekki sé vænlegt að skýra próunina með tilvísun til einstakra atburða eða persóna og ávirðinga peirra eins og oft er gert á kirkjulegum vettvangi. Slík tilvik geta pó vissulega skýrt einstakar sveiflur til dæmis hvað áhrærir úrsagnir úr kirkjunni.

Sú próun kirkjustofnunarinnar sem gerð hefur verið grein fyrir endurspeglast í sögu prestastéttarinnar sem hér var rakin enda hefur hún gegnt fyrirferðarmiklu hlutverki bæði í kirkjunni og samfélaginu. Áður fyrr var 
stéttin ósamstæð hvað menntun, efnahag og menningu áhrærði, stór hluti hennar átti samleið að minnsta kosti með peim hópi bænda sem betur voru settir og hafði breiðan snertiflöt við mikinn hluta pjóðarinnar. Síðar varð hún samstæð stétt háskólamenntaðra sérfræðinga sem gegnir hlutverkum á afmörkuðu sviði samfélagsins sem orðið er framandi fyrir mörgum og tengist í huga ýmissa einkum fæðingu og dauða og nokkrum öðrum áföngum í lífi einstaklinga eða fjölskyldna gjarna pegar á bjátar.

Sökum pess hve sterkrar trúarlegrar, guðfræðilegrar og sögulegrar helgi siðir, hefðir og venjur af ýmsu tagi njóta í kirkjunni hefur henni ekki tekist sem skyldi að fylgja próun samfélagsins eftir né heldur að laga sjálfskilning sinn og stofnunarmenningu að nýjum aðstæðum. Pegar íslenska pjóðkirkjan mætti nútímanum fyrir alvöru um miðbik tuttugustu aldar var hún bví svo til hreinræktuð stofnunar-, „sveita-“ og prestakirkja af pví tagi sem hér hafði starfað um aldir. Stofnunarkirkjan tók vissulega að láta undan síga á tveimur síðustu áratugum nítjándu aldar pegar um starf hennar í sóknum og prestaköllum er að ræða. Um pað leyti tóku söfnuðir að öðlast vaxandi hlutdeild í stjórn eigin mála. Á landsvísu hófst próunin ekki fyrr en komið var fram á tuttugustu öld einkum pegar kirkjuping kom til sögunnar. „Sveitakirkja“ með einhæfa starfshætti tók ekki að láta undan síga fyrr en komið var fram undir miðja tuttugustu öld. Lengst hefur prestakirkjan haldið velli og er raunar enn við lýði pegar tveir áratugir eru liðnir af tuttugustu og fyrstu öldinni. Hefur pessi hægfara stofnunarbróun kirkjunnar einangrað hana í samfélaginu.

Ekki er furða pótt pessar altæku breytingar endurspeglist í fjölda peirra sem tilheyra pjóðkirkjunni, trúa eins og hún eða samsama sig með henni á annan hátt. Vilji pjóðkirkjan hafa áhrif á pá próun og par með styrkja stöðu sína í náinni framtíð virðist lausnarinnar að leita í pví að hún haldi áfram að próa starfshætti sína frá pví sem tíðkaðist í stofnunar-, „sveita-“ og prestakirkju fyrri tíma í átt til „péttbýliskirkju“. Með pví gæti hún öðlast styrka stöðu innan priðja geira samfélagsins og par með haldið áfram að stuðla að aukinni velferð og farsæld meðal landsmanna hvað svo sem lagalegri eða félagslegri stöðu hennar líður. 


\section{ÚT D RÁTTUR}

Miklar breytingar hafa orðiðá stöðu íslensku pjóðkirkjunnar á peim tveimur áratugum sem liðnir eru af tuttugustu og fyrstu öldinni. Á peim tíma hefur hlutfall peirra sem tilheyra pjóðkirkjunni fallið um 25 prósentustig eða úr 89 í 63 prósent landsmanna. Til samanburðar tilheyrðu yfir 90 prósent pjóðkirkjunni 1985. Pví má segja að staða pjóðkirkjunnar sé á hverfanda hveli. Meðal kirkjufólks er pessi próun skýrð með pví að óánægju gæti meðal pjóðarinnar með kirkjustofnunina á landsvísu og par með yfirstjórn kirkjunnar en ekki starf hennar í héraði. Í greininni eru skýringar af pessu tagi taldar byggjast á gamaldags persónu- og atburðahverfum söguskilningi og leitast við að varpa ljósi á próunina út frá samfélagslegum söguskilningi. Gengið er út frá pví að skýringarnar á breyttri stöðu pjóðkirkjunnar stafi öðru fremur af próun íslenska samfélagsins úr hefðbundu, einföldu sveitasamfélagi í fjölgreint, nútímalegt péttbýlissamfélag sem tekur örum breytingum. Í kirkjunni njóta ýmsir siðir, venjur og hefðir á hinn bóginn ríkari trúarlegrar, guðfræðilegrar og sögulegrar helgi en á flestum sviðum samfélagsins. Af peim sökum hefur myndast misgengi milli kirkjunnar og samfélagsins sem kemur fram í pví að íslenska pjóðkirkjan er enn að verulegu leyti „sveita-“, stofnunar- og prestakirkja af líku tagi og hér starfaði áður en fyrrnefndar samfélagsbreytingar hófust. Til að skýra petta skýringarlíkan frekar er stiklað á stóru varðandi breytingar á stöðu og hlutverkum kirkjunnar og prestastéttarinnar á Íslandi á ýmsum skeiðum kirkjusögunnar.

Lykilorð: Íslenska pjóðkirkjan, samfélagsbreytingar, félagsleg staða pjóðkirkjunnar, íslensk kirkjusaga

\section{A B S T R A C T}

\section{All Things Are Flowing: On the Changed Status of the National Church of Iceland}

Great changes have occurred regarding the social status of the National Church of Iceland since the beginning of the twenty-first century. During that time, the membership has fallen by 25 percentage. Clergymen and others active in the local parishes often claim that this development can be attributed to a general dissatisfaction with the institution at the national level and thus with the church leaders. However, they state that this dissatisfaction does not apply to church life in the parishes. In the article, such explanations are considered to be based on an old-fashioned person- and event-oriented understanding of history. Instead, 
the author interprets the development from a social-historical point of view. He assumes that the explanations of the changed social status of the church are principally to be found in the development of the Icelandic society from a simple traditional, rural community to a multifaceted, modern, urban community undergoing rapid changes. However, various practices and traditions within the church maintain a rich religious, theological, and historical sanctity. As a result, a certain discrepancy has arisen between the church and the community, which is reflected in the fact that the National Church of Iceland is still to a large extent an old-fashioned, "rural", institutional, and clergy-oriented church, like the one operated in the country before the modernization of the society.

Keyzords: Icelandic church history, social changes, The National Church of Iceland, the social status of the church

\section{Hjalti Hugason}

Prófessor í kirkjusögu

guðfræði- og trúarbragðafræðideild

Hugvísindasviði Háskóla Íslands

Sæmundargötu 2

IS-102 Reykjavík, Ísland

hhugason@hi.is 